OPEN ACCESS

Edited by:

Jayachandran N. Kizhakkedathu, The University of British Columbia,

Canada

Reviewed by: Nayeli Alva-Murillo, University of Guanajuato, Mexico Elio Pizzo,

University of Naples Federico II, Italy

*Correspondence:

Nicolas Lévêque

nicolas.leveque@chu-poitiers.fr

Specialty section:

This article was submitted to Antimicrobials, Resistance

and Chemotherapy,

a section of the journal

Frontiers in Microbiology

Received: 30 September 2019 Accepted: 06 May 2020

Published: 03 June 2020

Citation: Chessa C, Bodet C, Jousselin C, Wehbe M, Lévêque N and Garcia M (2020) Antiviral and Immunomodulatory Properties of Antimicrobial Peptides Produced

by Human Keratinocytes.

Front. Microbiol. 11:1155.

doi: 10.3389/fmicb.2020.01155

\section{Antiviral and Immunomodulatory Properties of Antimicrobial Peptides Produced by Human Keratinocytes}

\author{
Céline Chessa ${ }^{1,2}$, Charles Bodet ${ }^{2}$, Clément Jousselin ${ }^{1,2}$, Michel Wehbe ${ }^{2}$, \\ Nicolas Lévêque ${ }^{1,2 *}$ and Magali Garcia ${ }^{1,2}$ \\ 'Laboratoire de Virologie et Mycobactériologie, CHU de Poitiers, Poitiers, France, ${ }^{2}$ Laboratoire Inflammation, Tissus \\ Epithéliaux et Cytokines, LITEC EA 4331, Université de Poitiers, Poitiers, France
}

Keratinocytes, the main cells of the epidermis, are the first site of replication as well as the first line of defense against many viruses such as arboviruses, enteroviruses, herpes viruses, human papillomaviruses, or vaccinia virus. During viral replication, these cells can sense virus associated molecular patterns leading to the initiation of an innate immune response composed of pro-inflammatory cytokines, chemokines, and antimicrobial peptides. Human keratinocytes produce and secrete at least nine antimicrobial peptides: human cathelicidin LL-37, types 1-4 human $\beta$-defensins, S100 peptides such as psoriasin (S100A7), calprotectin (S100A8/9) and koebnerisin (S100A15), and RNase 7. These peptides can exert direct antiviral effects on the viral particle or its replication cycle, and indirect antiviral activity, by modulating the host immune response. The purpose of this review is to summarize current knowledge of antiviral and immunomodulatory properties of human keratinocyte antimicrobial peptides.

Keywords: keratinocyte, antimicrobial peptide, innate immunity, antiviral, immunomodulation

\section{INTRODUCTION}

As the largest organ of human body, skin is not only a physical barrier but represents also the first line of defense against environmental pathogens including viruses (Robert and Kupper, 1999; Ganz, 2002). Skin is organized in three layers, which differ structurally and functionally: epidermis, the most superficial, dermis and hypodermis, the deepest. The epidermis is mainly composed of keratinocytes at different levels of differentiation, from the stratum basale made of the youngest keratinocytes, still dividing, at the dermis interface to the keratin containing desquamating corneocytes on the surface of the skin. Langerhans cells (LCs), a skin-specialized type of dendritic cells (DCs) constantly probing for antigens, represent the main immune resident cell in the epidermis (Kubo et al., 2009). T cells, mainly CD8+, can also be found in the deepest strata, stratum basale, and stratum spinosum, of the epidermis (Nestle et al., 2009). Finally, melanocytes, responsible for the pigmentation of the skin, constitute the last cell type of the epidermis (Nestle et al., 2009). Then, the dermis is a more complex conjunctive tissue composed of several specialized cells, such as DCs, CD4 + T helper (Th)1, Th2, and Th17 cells, $\gamma \delta$ T cells, macrophages, mast cells, and fibroblasts, which all together play a role in the immune skin barrier. Contrary to the epidermis, the dermis is an innervated tissue where blood and lymphatic vessels contribute to cell trafficking (Nestle et al., 2009). Finally, hypodermis is an adipose-tissue mainly composed of fat cells. 
Keratinocytes allow, in vivo and in vitro, replication of many viruses such as alphaherpesviruses [types 1 and 2 herpes simplex viruses (HSV), varicella-zoster virus (VZV)], arboviruses such as Dengue (DENV), Zika (ZIKV), and West Nile viruses (WNV), enteroviruses, human papillomaviruses (HPVs) and vaccinia virus (VACV), amplifying the viral load and facilitating viral spread to the liver, the fetus or the central nervous system (Lim et al., 2011; Crack et al., 2012; Puiprom et al., 2013; Sayers and Elliott, 2016; Gourru-Lesimple et al., 2017; Phyu et al., 2017; Duangkhae et al., 2018). Keratinocytes also act as immune cells that can initiate an innate immune response to fight viral infection (Nestle et al., 2009). Indeed, they express a wide range of Pattern-Recognition Receptors (PRRs) including cell-surface $(-1,-2,-4,-5,-6)$ or endosomal $(-3,-7,-8,-9)$ transmembranal Toll-Like Receptors (TLRs). They also possess cytosolic sensors like Retinoic acid Inducible Gene I (RIG-I)-Like Receptors (RLRs): Melanoderma Differentiation-Associated gene 5 (MDA5), Retinoic acid-Inducible gene (RIG-I) and Laboratory of Genetics and Physiology 2 (LGP2), or cytosolic DNA receptor cyclic GMP-AMP Synthase (cGAS) (Almine et al., 2017; Nestle et al., 2009). All these PRRs sense Pathogen Associated Molecular Patterns (PAMPs) that are, in case of viruses, nucleic acid and structural or non-structural protein motifs conserved among pathogens (Yong and Luo, 2018). For RNA viruses, such as arboviruses and enteroviruses, the main PRRs involved in the detection of the viral infection are TLRs 3 and 7, and RLRs RIG-I and MDA5, detecting single-stranded viral genomes or doublestranded replication intermediates in endosomes and cytoplasm, respectively. Activation of these PRRs triggers signaling pathways leading to production of interferons (IFNs), proinflammatory chemokines, cytokines and antimicrobial peptides (AMPs) that are key players of the innate immune response Kalali et al., 2008; Nestle et al., 2009; Takeuchi and Akira, 2009; Welte et al., 2009; Aguirre et al., 2012; Dalpke and Helm, 2012; Garcia et al., 2017). Then, secreted pro-inflammatory mediators participate to the recruitment of monocytes, macrophages, polymorphonuclear neutrophils (PMNs), and DCs to the site of viral infection (Schmid and Harris, 2014; Pingen et al., 2016; Sharif et al., 2016). These cells are innate immune sentinels playing a crucial role in activation of innate and adaptive antiviral immunities. For example, once activated by a viral antigen, LCs and DCs start migrating to the draining lymph node in order to prime T-cells and induce an immune memory (Johnston et al., 1996, 2000; Kubo et al., 2009). Other skin cells can also contribute to the initiation of the innate immune response. It has been suggested that melanocytes were contributing to the phagocytosis of viral pathogens, presenting antigens to competent immune cells or producing cytokines and chemokines (Gasque and Jaffar-Bandjee, 2015). Overall, these data highlight the crosstalk between the different kinds of skin cells in order to create an antiviral environment. Thus, in the same way as respiratory, genital or digestive epithelia, the cutaneous epithelium is an interface between the organism and the outside environment exposed to many microorganisms, functioning as a physical but also as an immunological barrier (Grice and Segre, 2011). Antimicrobial defense is therefore essential in order to preserve the "aseptic" of deep skin tissue. For this purpose, AMPs, which are small peptides synthesized and secreted by skin cells and glands, display antifungal, antibacterial and both direct and indirect antiviral activities (Zasloff, 2002). Indeed, they can directly inactivate viral particles or inhibit virus replication (Wilson et al., 2013). AMPs can also exert an indirect antiviral activity by modulating the host immune response. They can induce the production of cytokines and chemokines, demonstrating both proper pro-inflammatory activities and potentiating the inflammatory response caused by the infection. AMPs may also exert a chemo-attractant activity on immune cells at the site of infection contributing to viral clearance (De et al., 2000; Koczulla and Bals, 2003; Tjabringa et al., 2006; Lai and Gallo, 2009; Mookherjee et al., 2009).

The purpose of this review is to summarize current knowledge about direct antiviral and immunomodulatory properties of human keratinocyte antimicrobial peptides.

\section{MAIN CHARACTERISTICS OF ANTIMICROBIAL PEPTIDES PRODUCED BY HUMAN KERATINOCYTES AND EXPRESSION IN THE CONTEXT OF VIRAL INFECTION}

Antimicrobial peptides are small peptides, classically less than 100 amino-acids, with a large structural diversity (Lehrer and Ganz, 1999; Lei et al., 2019). They can form $\alpha$-helices, cysteine-rich pleated $\beta$-sheets with one or more disulfide bridges, or be relatively non-structured peptides containing a high percentage of one specific type of amino-acid (Lehrer and Ganz, 1999). Human keratinocytes are known to produce and secrete at least nine AMPs: human cathelicidin LL-37, types 1-4 human $\beta$-defensins, psoriasin (S100A7), calprotectin (S100A8/9), koebnerisin (S100A15), and RNase 7 (Braff et al., 2005; Lai and Gallo, 2009). Their expression can be constitutive or inducible, displaying an increased expression in case of stimuli such as infection or inflammation. In addition, incubation of primary human keratinocytes with pro-inflammatory cytokines can stimulate AMP synthesis (Guilloteau et al., 2010; Firat et al., 2014).

\section{Human Cathelicidin LL-37}

LL-37 is the only known human cathelicidin, although peptides of this large family have been isolated from numerous nonhuman species. This amphipathic $\alpha$-helical peptide is produced by human keratinocytes during inflammatory disorders like psoriasis, lupus erythematosus and contact dermatitis where its concentration can reach $20 \mu \mathrm{g} / \mathrm{mL}$ (Frohm et al., 1997; Braff et al., 2005; Currie et al., 2013). Its up-regulation has also been described during HSV-2 and DENV infections of human keratinocytes (Ogawa et al., 2013; López-González et al., 2018). Moreover, LL-37 expression in combination with hBD-3 was also increased in epidermal and dermal lesions of patients suffering from Kaposi's sarcoma caused by human herpes virus 8 (HHV-8) in comparison to normal skin of healthy controls (Fathy et al., 2012). Finally, the secretion of LL-37 was observed during the 
infection of the respiratory epithelium by human rhinovirus (HRV) C, influenza virus A (IAV)/H1N1 and respiratory syncytial virus (RSV) (Hansdottir et al., 2008; Boda et al., 2018). In cell culture supernatant of infected nasal epithelium, LL-37 secretion ranged from 10 to $25 \mathrm{ng} / \mathrm{mL}$. Interestingly, its secretion was not detected following HRV-B and coronavirus (HCoV-) OC43 infection potentially related to a different cell tropism of these two viral species (Boda et al., 2018).

\section{$\beta$-defensins}

Defensins are small molecules between 24 and 42 amino-acids characterized by a $\beta$-sheet structure with 3 disulfide bounds. In human, defensins are divided into $\alpha$-defensins, referred to as human neutrophil peptides (hNPs), and $\beta$-defensins (hBDs) expressed in myeloid and epithelial cells. There are about 37 hBDs (Wilson et al., 1999; Holly et al., 2017). Four (hBD-1 to -4$)$ are detected in the epidermis. Many viruses were shown to stimulate hBD expression and/or secretion in epithelial cells, even though the antiviral activity of these peptides was not always demonstrated (Frohm et al., 1997). In human keratinocytes, VACV, DENV and HSV-2 infections were shown to induce hBD-1, hBD-2, and -3 , and hBD-4 expression, respectively (reviewed in Surasombatpattana et al., 2011; Wilson et al., 2013). HPV infection also increased hBD1 to -3 expression in oral epithelial lesions from patients with recurrent respiratory papillomatosis (Chong et al., 2006). $\mathrm{hBD}$ production was then demonstrated in vulvovaginal biopsy samples of condylomata acuminata as well as in human amniotic epithelial cells infected with HPV (Erhart et al., 2011; Szukiewicz et al., 2016). Interestingly, expression of hBD-2 was paradoxically diminished in HPV-induced carcinomas potentially defining a mechanism of virus escape to the host immune response occurring during carcinogenesis (Hubert et al., 2007). Type 1 human immunodeficiency virus (HIV-1) infection also induced expression of hBD-2 and -3 , but not that of hBD-1, in human oral epithelial cells (Quiñones-Mateu et al., 2003). In respiratory epithelial cells infected in vitro, hBD-2 and hBD-3 production is stimulated by the replication of several HRV serotypes from HRV-B and -C species. In vivo, a doubling of the concentration of hBD2, from $150 \mathrm{ng} / \mathrm{mL}$ to more than 300 , was assessed at 48 $\mathrm{h}$ post-infection in nasal swabs of patients infected with HRVA16 (Proud et al., 2004). Similarly, IAV/H1N1 as well as RSV infections induced a huge increase in $\mathrm{hBD}-2$ secretion whereas HCoV-OC43 did not (Kota et al., 2008; Boda et al., 2018). In intestinal epithelial cells, enterovirus (EV) infection enhanced the secretion of hBD- 3 but not that of $\alpha$ - and other $\beta$-defensins (Chen et al., 2018). In fresh peripheral blood mononuclear cells, the other major source of hBD production in human, only hBD-1 coding mRNAs were detected in non-stimulated cells among the four known hBDs (Oppenheim et al., 2003). Its expression could be then induced as early as $3 \mathrm{~h}$ postinfection with IAV, Sendai virus or, in a much lesser extent, HSV-1 (Ryan et al., 2011). Finally, hBD concentrations have been demonstrated to be elevated after exposure to Hepatitis $\mathrm{B}(\mathrm{HBV})$ and $\mathrm{C}(\mathrm{HCV})$ viruses as well as to Crimean-Congo hemorrhagic fever virus (CCHFV) (Bai et al., 2015; Aksoy et al., 2016; Mattar et al., 2016a). Concentrations of hBDs were shown to be significantly higher in $\mathrm{HCV}$-infected patient sera, ranging from 900 to $21,120 \mathrm{ng} / \mathrm{mL}$, compared to controls where they were less than $60 \mathrm{ng} / \mathrm{mL}$ (Mattar et al., 2016a). In the same way, serum hBD2 levels were significantly increased in patients infected with CCHFV compared to healthy controls and were three-times higher in patients with non-fatal evolution of the disease than in patients with fatal disease $(89,480$ vs. 30,580 $\mathrm{ng} / \mathrm{mL}$ ) suggesting a protective role of the peptide during the infection (Aksoy et al., 2016).

\section{Peptides of the S100 Family}

S100 family peptides are characterized by two calciumbinding sites that can also chelate zinc and manganese. This family regroups 25 molecules among those psoriasin S100A7, calprotectin S100A8/9 and koebnerisin S100A15 are produced by keratinocytes (Celis et al., 1990; Zhu et al., 2013). Constitutive expression of psoriasin S100A7 is low in normal adult skin ranging from 5 to $46 \mathrm{ng} / \mathrm{cm}^{2}$ regarding to the region of the human body (Gläser et al., 2005). Its expression can be enhanced in stimulated keratinocytes as seen in psoriasis (Gläser et al., 2005). Conversely, high expression levels have been detected in the fetal skin, suggesting a potentially protective role in the innate immune system of the newborn (Yoshio et al., 2003). Besides its antimicrobial activity, S100A7 is associated with wound healing, neutrophil migration, Reactive Oxygen Species (ROS) generation, antimicrobial peptide release and cytokine/chemokine production (Niyonsaba et al., 2008; Kozlyuk et al., 2019). S100A7 has further been reported to be overexpressed in breast and bladder tumors, suggesting that it may play a role in the regulation of cell growth, survival and differentiation (Watson et al., 1998; Ostergaard et al., 1999). Regarding viral infections, psoriasin expression is induced in vulvovaginal and cervical HPV-associated lesions (Erhart et al., 2011; Alvendal et al., 2019). Calprotectin S100A8/9 is a heterodimer composed of calgranuline A (S100A8 or myeloid-related protein 8) and calgranuline B [S100A9 or migration inhibitory factor-related protein 14 (MRP14)]. In normal epidermis, S100A8 and S100A9 are both expressed at low levels but, in inflammatory skin diseases such as psoriasis, lichen planus and lupus erythematosus, or during wound healing, their expression is highly induced (Gabrielsen et al., 1986; Kunz et al., 1992; Thorey et al., 2001). Moreover, S100A8/9 expression has been identified as a general danger signature of activated keratinocytes, as its expression can be induced in response to a wide variety of skin stresses including tape stripping, exposure to detergent, UV or cytokine stimulation (IL-1 $\alpha$, IL-22) (Boniface et al., 2005; Ehrchen et al., 2009). This overexpression prevents keratinocyte proliferation but triggers cell differentiation (Ryckman et al., 2003; Voss et al., 2011). Calprotectin expression has been also shown to be increased in epithelial cells during viral infections by coronavirus and HPV with antiviral properties against HPV type 16 (Reghunathan et al., 2005; Tugizov et al., 2005). Finally, koebnerisin S100A15, which has a sequence almost identical to that of psoriasin, is overexpressed in psoriatic skin lesions and known for its proinflammatory and chemotaxis properties (Wolf et al., 2011). Infection with Escherichia coli also modulates its expression in 
keratinocytes through recognition of the pathogen by TLR4 (Büchau et al., 2007). To our knowledge, S100A15 expression in the context of viral infection has so far never been studied.

\section{RNase 7}

While RNase 7 is usually considered as an AMP, it is actually a larger protein of $14.5 \mathrm{kDa}$, composed of 128 amino acids and belonging to the RNase A superfamily. RNase 7 exhibits potent ribonuclease activity and its expression in the skin is both constitutive and inducible in inflammatory and infectious contexts (Harder and Schroder, 2002; Simanski et al., 2013; Firat et al., 2014). In normal skin, RNase 7 concentration varies according to the area of the body, from $0.17 \mathrm{ng} / \mathrm{cm}^{2}$, in the palms of the hands, to $1.28 \mathrm{ng} / \mathrm{cm}^{2}$, in skin of the legs (Rademacher et al., 2016). RNase 7 concentrations are increased in patients with psoriatic, atopic dermatitis and dermatophyte skin lesions (Becknell and Spencer, 2016). In vitro studies have demonstrated that the treatment of primary keratinocytes with proinflammatory cytokines such as IL-17A, TNF- $\alpha$, IL-1 $\beta$, and IFN- $\gamma$ or their infection with Pseudomonas aeruginosa, Staphylococccus aureus, Staphylococcus epidermidis, Corynebacterium amycolatum, Escherichia coli, Enterococcus faecium or the dermatophyte Trichophyton rubrum induced RNase 7 expression (reviewed in Becknell and Spencer, 2016; Rademacher et al., 2019). Keratinocyte infection with DENV was also shown to induce RNase 7 gene expression (Surasombatpattana et al., 2011).

The main characteristics of keratinocyte AMPs are summarized in Table 1.

\section{ANTIVIRAL ACTIVITIES OF KERATINOCYTE AMPS}

The antiviral activity of LL-37 has been reported against many viruses, both naked and enveloped as reviewed previously (Barlow et al., 2014; Ahmed et al., 2019a; Brice and Diamond, 2019). In particular, LL-37 was shown to inhibit viruses that replicate in the skin such as HSV-1 and -2, VZV, HHV-8, DENV, ZIKV, HPV16, or VACV (Howell et al., 2004; Buck et al., 2006; Hazrati et al., 2006; Crack et al., 2012; Alagarasu et al., 2017; Brice et al., 2018; He et al., 2018). Further antiviral activities were identified against viruses responsible for enteric infections such as Aichi virus A, respiratory diseases such as IAV, RSV and HRVs, and ocular epithelium infections such as adenoviruses (Gordon et al., 2005; Barlow et al., 2011; Uchio et al., 2013; Harcourt et al., 2016; Schögler et al., 2016; Findlay et al., 2017; Sousa et al., 2017; Vilas Boas et al., 2017). In vitro inhibition of HCV in hepatocytederived carcinoma HuH-7 cells and HIV in peripheral blood mononuclear cells (PBMCs) including CD4 $+\mathrm{T}$ cells was also described (Bergman et al., 2007; Matsumura et al., 2016). In vivo, the murine analog of LL-37, mCRAMP, reduced disease severity and IAV replication in the lung of infected mice to a similar extent as neuraminidase inhibitors (Barlow et al., 2011).

In the context of skin infections, antiviral properties of hBDs have been demonstrated against HSV, VZV, and VACV, similarly to LL-37, but also against EV-71 and Coxsackievirus
(CV) A16, the main etiological agents of hand, foot and mouth disease (Hazrati et al., 2006; Howell et al., 2004; Crack et al., 2012; Chen et al., 2018). hBD-3, and in a lesser extent hBD1, exerted anti-HSV-2 activities whereas hBD-2 did not but diminished VZV replication in HaCat cells, a keratinocyte cell line (Hazrati et al., 2006; Scudiero et al., 2010). Moreover, hBD3 , but not hBD-2, significantly reduced the expression of the VACV DNA-dependent RNA polymerase and the number of viral plaques in African green monkey kidney cell line BS-C1 in a concentration-dependent manner from $5 \mu \mathrm{M}$ (Howell et al., 2007). Finally, addition of recombinant hBD-3 to colon adenocarcinoma HT-29 cells inhibited EV-71, CV-A16, CV-B5, and poliovirus 1 infection. However, enterovirus replication was not impaired in genetically modified HT-29 cells overexpressing hBD-3 intracellularly, suggesting extracellular antiviral activity of the peptide (Chen et al., 2018). Regarding other viral species, hBD-1 and, more markedly, hBD-2 neutralized infectivity of the Phil82 strain of IAV (Doss et al., 2009). Antiviral activity of hBD-2 was also shown against RSV and type 3 human parainfluenza virus (HPIV-3) (Kota et al., 2008). Treatment of human lung epithelial A549 cells with $4 \mu \mathrm{g} / \mathrm{mL}$ hBD-2 reduced RSV and HPIV-3 viral titers by more than 100 -fold whereas hBD1 treatment had no effect against these two respiratory viruses (Kota et al., 2008). In addition, hBD-1 to -3 have been shown to render less infectious HIV-1 virion particles. Interestingly, this effect was higher when combining hBD-2 and hBD-3 than that of the peptides added separately (Quiñones-Mateu et al., 2003; Sun et al., 2005). Finally, hBD-1 to -4 , used at 10,20 , and $50 \mu \mathrm{g} / \mathrm{mL}$, diminished HCV gene expression and cytotoxicity associated with infection in PBMCs and HuH7.5 liver cell line (Mattar et al., 2016b). Conversely, other studies aimed at describing hBD antiviral properties found little or no activity. For example, hBD1 and hBD-2 peptides had no effect on HPV16 infection of the cervical cancer cell line HeLa (Buck et al., 2006). However, polymorphisms in the gene DEFB1, encoding hBD-1, has been associated with higher susceptibility to HPV infection suggesting nevertheless a role for this peptide in the antiviral response. In the same way, BK and JC viruses were not or modestly inhibited by hBD-1 and hBD-2 while hBD-2 was found to be ineffective against HRVs (Dugan et al., 2008). Overall, the antiviral properties of hBDs are sometimes restricted to a given viral species suggesting a specific mechanism of action depending on the structure of the viral particle or its replication cycle. Finally, their ability to inhibit viral infection generally appears to be lower than that of LL-37 or other defensins.

To our knowledge, antiviral activity of psoriasin S100A7, calprotectin S100A8/9, and koebnerisin S100A15 has so far never been studied despite induction of their expression during many viral infections as described above. Similarly, RNase 7, despite its abundance in the skin, induction of its expression in an inflammatory or infectious context, and its high antimicrobial activity demonstrated in vitro against a broad spectrum of microorganisms such as Gram-positive and Gram-negative bacteria like Pseudomonas aeruginosa, Staphylococcus aureus, Enterococcus faecium, Mycobacterium vaccae, the yeast Candida albicans and Pichia pastoris, and the dermatophyte Trichophyton rubrum, has so far poorly been tested against viruses (Pulido 
TABLE 1 | Main characteristics of the antimicrobial peptides synthesized by the keratinocyte.

\begin{tabular}{|c|c|c|c|c|}
\hline AMP & Producing cells & Structure & Properties & References \\
\hline LL-37 & $\begin{array}{l}\text { Keratinocytes, monocytes, } \\
\text { mast cell granules, PMNs, } \\
\text { natural killer (NK) cells, } \\
\text { sweat glands }\end{array}$ & $\begin{array}{l}\text { N-terminus signal peptide, } \\
\text { cathelin domain, and } \\
\text { C-terminus peptide }\end{array}$ & $\begin{array}{l}\text { Antimicrobial, chemotaxis, } \\
\text { cytokine/chemokine } \\
\text { production, cell } \\
\text { migration/proliferation }\end{array}$ & $\begin{array}{l}\text { Frohm et al., 1997; } \\
\text { Sørensen et al., 2001; } \\
\text { Murakami et al., 2002; Di } \\
\text { Nardo et al., 2003; Braff } \\
\text { et al., 2005) }\end{array}$ \\
\hline hBD1 & $\begin{array}{l}\text { Keratinocytes, monocytes, } \\
\text { macrophages, DCs, } \\
\text { sebaceous glands, canals } \\
\text { of the sudoriparous glands }\end{array}$ & $\begin{array}{l}3 \text { antiparallel beta sheets } \\
\text { structure, and } 3 \text { disulfide } \\
\text { bonds }\end{array}$ & $\begin{array}{l}\text { Antimicrobial, chemotaxis, } \\
\text { cytokine/chemokine } \\
\text { production, wound healing, } \\
\text { proinflammatory } \\
\text { mediators/suppressors }\end{array}$ & $\begin{array}{l}\text { Fulton et al., 1997; Ali et al., } \\
\text { 2001; Semple and Dorin, } \\
\text { 2012; Pace et al., } 2017\end{array}$ \\
\hline hBD2 & $\begin{array}{l}\text { Keratinocytes, monocytes, } \\
\text { macrophages, DCs }\end{array}$ & & & \\
\hline hBD3 & Keratinocytes & & & \\
\hline hBD4 & Keratinocytes & & & \\
\hline S100A7 & Keratinocytes & $\begin{array}{l}1 \text { monomer consists of } 5 \\
\text { helices each and carries } \\
\text { only } 1 \text { calcium-binding } \\
\text { EF-hand }\end{array}$ & $\begin{array}{l}\text { Antimicrobial, chemotaxis, } \\
\text { cytokine/chemokine } \\
\text { production, wound healing, } \\
\text { neutrophil migration, } \\
\text { epithelial tumor progression } \\
\text { marker }\end{array}$ & $\begin{array}{l}\text { Gläser et al., 2005; Wolf } \\
\text { et al., } 2011\end{array}$ \\
\hline S100A8/9 & $\begin{array}{l}\text { Keratinocytes, } \\
\text { macrophages, PMNs }\end{array}$ & & $\begin{array}{l}\text { Antimicrobial, chemotaxis, } \\
\text { cytokine/chemokine } \\
\text { production, antitumoral, } \\
\text { antinociceptive }\end{array}$ & Ryckman et al., 2003 \\
\hline S100A15 & $\begin{array}{l}\text { Basal keratinocytes, } \\
\text { melanocytes, DCs, LCs, } \\
\text { sebocytes, smooth } \\
\text { muscles and endothelial } \\
\text { cells of the dermis }\end{array}$ & & $\begin{array}{l}\text { Antimicrobial, chemotaxis, } \\
\text { cytokine/chemokine } \\
\text { production, wound healing, } \\
\text { neutrophil migration, } \\
\text { epithelial tumor progression } \\
\text { marker }\end{array}$ & $\begin{array}{l}\text { Wolf et al., 2011; Hattinger } \\
\text { et al., } 2013\end{array}$ \\
\hline RNase 7 & Keratinocytes & $\begin{array}{l}\text { Hydrophobic signal } \\
\text { peptide, mature peptide } \\
\text { (12-16 kDa) with 3-4 } \\
\text { disulfide bounds }\end{array}$ & $\begin{array}{l}\text { Antimicrobial, } \\
\text { immunomodulation }\end{array}$ & $\begin{array}{l}\text { Becknell and Spencer, } \\
2016 \text {; Rademacher et al., } \\
2016\end{array}$ \\
\hline
\end{tabular}

AMP, Antimicrobial peptide; PMNs, polymorphonuclear neutrophils; DCs, dendritic cells; LCs, Langerhans cells.

et al., 2013; Rademacher et al., 2016). Recently, it was reported that RNase 7 failed to reduce HSV-1 infection in keratinocytes (Kopfnagel et al., 2020).

\section{DIRECT ANTIVIRAL EFFECTS OF KERATINOCYTE AMPS}

AMPs can inhibit viral infection by targeting the steps preceding the entry of the virus into the cell but also intracellular stages of viral replication (Ahmed et al., 2019a). Before virus entry, they can directly alter viral particles by creating pores within the viral envelope thanks to their cationic and amphiphilic nature (Hsieh and Hartshorn, 2016). Electron microscopy observation of VACV and RSV, respectively exposed to LL-37 and hBD2 , thus showed a disruption of the viral envelope (Watson et al., 1998; Howell et al., 2004; Niyonsaba et al., 2005; Kota et al., 2008). LL-37-related inhibition of HHV-8 internalization in oral epithelial cells (OECs) relied on the same mechanism. The authors showed that LL-37 did not alter OECs, but, instead, the virions by disrupting the viral envelope then preventing viral entry into epithelial cells. This was observed from concentration of $10 \mu \mathrm{g} / \mathrm{mL}$ compatible with concentrations measured during inflammation in epithelial tissue reaching up to $20 \mu \mathrm{g} / \mathrm{mL}$ (Currie et al., 2013; Brice et al., 2018). Pre-incubation of ZIKV, IAV, VACV, and HCV with LL-37, or one of its analog, resulted in a significant decrease in the number of active virions suggesting, here again, an alteration of the viral particle (Ehrchen et al., 2009; Dean et al., 2010; Tripathi et al., 2013; Becknell and Spencer, 2016; Matsumura et al., 2016; Ulaeto et al., 2016; He et al., 2018). Similarly, hBDs, namely hBD-2, incubated with HIV, HPIV, and RSV also decreased virion infectivity, likely because of permeabilization of the viral envelope lipid bilayer since electron microscopy showed direct binding of hBDs to viral particles (Quiñones-Mateu et al., 2003; Kota et al., 2008). This detergentlike role is reported as the main AMP antiviral mechanism of action. However, direct interaction with AMPs can also cause viral particles extracellular aggregation blocking virus entry and leading to an increase of virus uptake by phagocytes. Treatment with LL-37 caused clumping of Venezuelan equine encephalitis virus (VEEV), thereby preventing cell infection (Ahmed et al., 2019b; Lai et al., 2011). Finally, the pre-fusion antiviral activity of AMPs can be linked to an inhibition of virus attachment to its receptor at the cell surface. LL-37 bound DENV-2 envelope 
protein acting as an entry inhibitor (Voss et al., 2011; Alagarasu et al., 2017). LL-37 also prevented HSV-1 infection in corneal epithelial cells by blocking viral-cell attachment (Sunahori et al., 2006; Lee et al., 2014). hBD-3 interacted with either the HSV receptor at the target cell surface or the HSV glycoprotein on the viral envelope, thereby eliciting a stronger inhibition of viral entry (Hazrati et al., 2006; Niyonsaba et al., 2008).

In addition to these antiviral properties based on the inhibition of the virus entry into the target cell, AMPs can interfere with intracellular steps of viral replication (Hazrati et al., 2006; Niyonsaba et al., 2008; Wilson et al., 2013). Indeed, several studies reported that AMPs added after the virus entry could lead to virus gene expression or genome replication inhibition (Howell et al., 2006; Crack et al., 2012; Currie et al., 2013; Sousa et al., 2017). Moreover, the hypothesis of intracellular antiviral activity of AMPs is supported by the fact that recombinant peptides added to the cell culture medium can be internalized by the epithelial cells (Lau et al., 2005). Unfortunately, most of the time, the exact mechanism of the post-fusion antiviral activity of AMPs is not clearly defined. An elegant study nonetheless described the anti-HIV-1 intracellular activity of LL-37 that occurs through direct protein-protein interactions with reverse transcriptase and, in a lesser extent, protease (Wong et al., 2011). In contrast, the LL-37 did not have the ability to prevent the translocation of HIV-1 integrase from the cytoplasm into the nucleus, which is its site of action. Furthermore, inhibition of early HIV-1 transcription by hBD-2 has also been reported (Klotman and Chang, 2006; Yong and Luo, 2018). Overall, the direct mechanisms by which AMPs inhibit virus infection remain little known, particularly regarding the intracellular steps of replication. The immunomodulatory functions of AMPs were, however, better studied, although much progress remains to be made in the context of viral infection.

\section{INDIRECT ANTIVIRAL ACTIVITIES THROUGH MODULATION OF THE HOST CELL IMMUNE RESPONSE}

\section{Induction of Cytokine and Chemokine Expression by Keratinocyte AMPs}

The expression of antimicrobial peptides synthesized by the keratinocyte is increased or induced in context of inflammation and/or infection. In turn, these peptides can stimulate the expression of cytokines and chemokines because of their own pro-inflammatory properties or by their capacity to potentiate an already in progress inflammatory response.

\section{Intrinsic Pro-inflammatory Properties of AMPs}

AMPs are known to have intrinsic pro-inflammatory properties through induction of various inflammatory mediator production by resident skin cells, such as keratinocytes, and cutaneous immune cells such as PBMCs and PMNs. AMPs act by binding cellular receptors leading to signaling pathway activation and up-regulation of cytokine or chemokine expression.
CC Chemokine Receptor 6 (CCR6), TLR4, and G ProteinCoupled Receptor (GPCR) are the three receptors identified so far with which AMPs interact to induce the cellular inflammatory response.

CCR6 is a seven-transmembrane domain G-protein-coupled receptor with only one known chemokine ligand, CCL-20, which was involved in DC, memory $\mathrm{T}$ cell and selected B cell subtype chemotaxis (Lee and Körner, 2017). hDB-3 binding to CCR6 upregulated IL-37 expression and release by human keratinocytes through caspase- 1 and -4 , mothers against decapentaplegic homolog 3 (SMAD3), mitogen activated protein kinase (MAPK) and nuclear factor-kappa B (NF-кB) pathway activation (Smithrithee et al., 2015).

TLR4 normally senses bacterial peptidoglycan and lipopeptides as well as viral envelop glycoproteins. Its interaction with S100A8 and S100A9 homodimers induced IL-1 $\beta$, IL-6, INF- $\gamma$, and TNF- $\alpha$ secretion in human PBMCs. Interestingly, S100A8/S100A9 heterodimer binding to TLR4 failed to induce this secretion (Chen et al., 2015). Furthermore, treatment with the recombinant S100A8-GST peptide stimulated macrophages, again through TLR4 activation, increasing TNF- $\alpha$, CCL-2, IL-1 $\beta$, IL-6, IL-12, IL-22, IL-23, and IL-24 mRNA expression and contributing to their migration (Figure 1; Inoue et al., 2018).

$\mathrm{G}$ protein-coupled receptor (GPCR) and phospholipase C (PLC) signaling pathway are involved in hBD-2, -3, and -4mediated induction of IL-6, IL-10, IFN- $\gamma$, CXL-10, CCL-2, and CCL-5 expression and secretion in human primary keratinocytes playing a role in their migration and proliferation (Figure 1; Niyonsaba et al., 2007).

Other signaling pathways have been described activated by the PAMPs expressed by keratinocytes even if the receptor involved has not always been identified. Niyonsaba et al. (2005) demonstrated that IL-18 mRNA expression and IL-18 secretion were induced by stimulation of keratinocytes with hBD-2, -3, 4 , but not -1 , and LL-37 through the phosphorylation of p38 and ERK1/2. Moreover, the involvement of p38 and ERK1/2 was also described in IL-6, CXCL-8, CCL-3, CCL-20, TNF- $\alpha$, and ROS production a dose- and time-dependent manner after human PMN treatment with S100A7 (Zheng et al., 2008). Similar results were obtained by addition of S100A7 to keratinocytes that increased production of CXCL-8, CXCL-10, and CCL20 (Niyonsaba et al., 2008). hBD-2 and, in a lesser extent, hBD-1 and $\mathrm{hBD}-3$ were shown to induce expression and secretion of IL-6, IL-10, and CXCL-8 in PBMCs in a dose-dependent manner (Boniotto et al., 2006). hBD-3 can also stimulate the expression of IL-1 $\alpha$, IL-6, CXCL-8, and CCL-18 in differentiated macrophages as well as CXCL-1, CCL-2, CCL-22, MIP-1 $\alpha$, IL-1 $\beta$, and VEGF in monocytes (Jin et al., 2010; Petrov et al., 2013). hBD-2 also causes pro-inflammatory cytokine secretion by lymphocytes through activation of JNK, MERK/ERK and PI3K/Akt pathways (Kanda et al., 2011). Concerning RNase 7, its ability to induce IFN$\alpha$ and IFN-stimulated gene expression in human plasmacytoid DCs and PBMCs has been reported (Kopfnagel et al., 2018). Finally, TNF- $\alpha$, IL-1 $\beta$, IL-6, and CXCL- 8 production observed in S100A8/A9-stimulated monocytes involved both p38 MAPK and NF- $\kappa \mathrm{B}$ signaling pathway activation in an independent manner (Figure 1; Sunahori et al., 2006). 


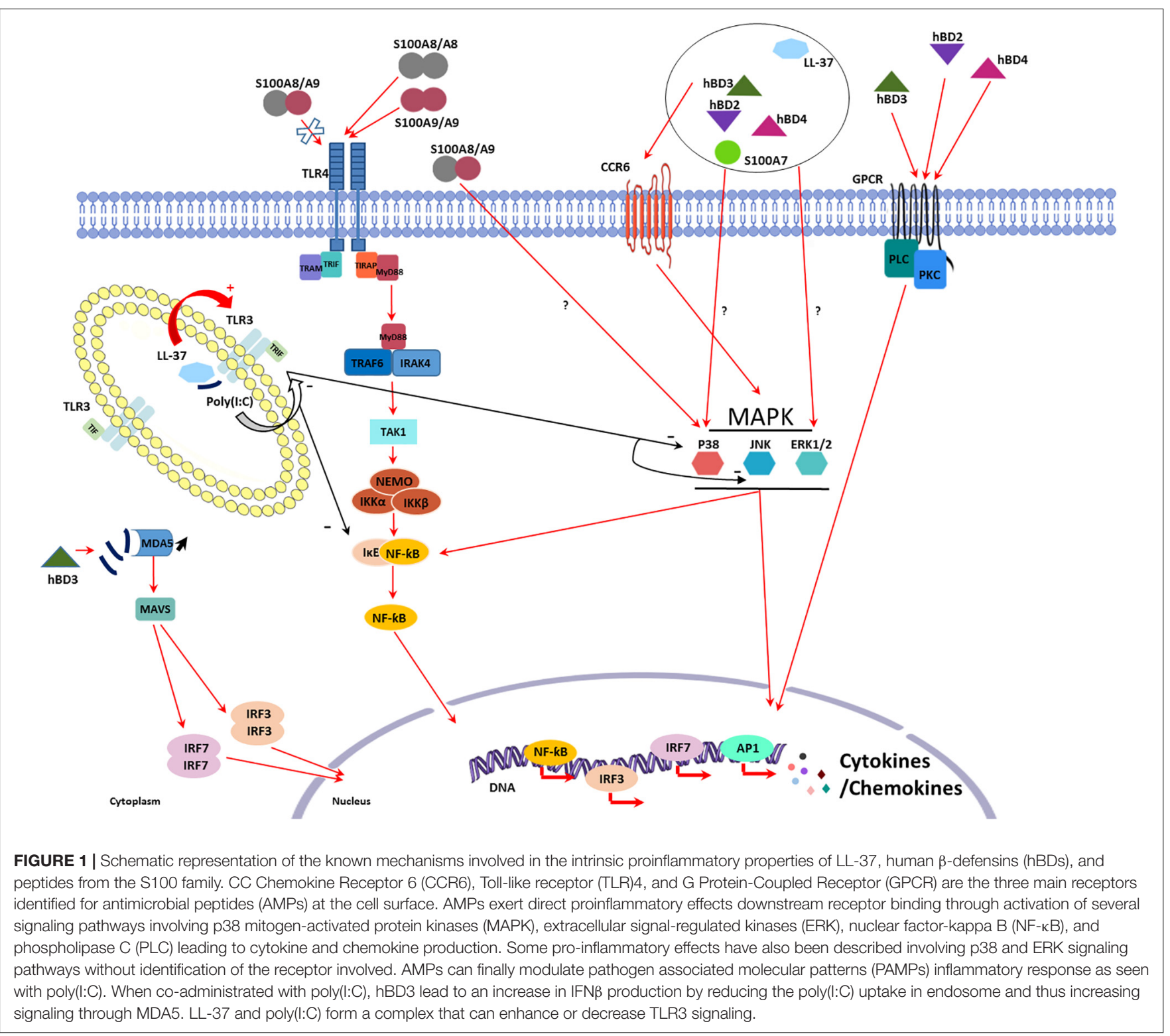

\section{Modulation of Inflammatory Response by AMPs}

Besides leading to cytokine and chemokine expression and secretion, AMPs can also contribute to enhance or inhibit inflammatory response induced by PAMPs.

Polyinosinic:polycytidylic acid [poly (I:C)] is a synthetic analog of double stranded RNA, mimicking a molecular pattern associated with viral replication known to activate TLR3, RIGI, and MDA5. LL-37 was shown to increase IFN $\beta-1$ mRNA expression induced by poly (I:C) stimulation in human epidermal keratinocytes leading to an enhanced antiviral activity against HSV-1 (Takiguchi et al., 2014; Sato et al., 2018). Lai et al. (2011) demonstrated that this LL-37-dependent enhancement of the inflammatory response required TLR3. Indeed, LL37 forms, with poly (I:C), a complex that enhances TLR3 signaling pathway (Singh et al., 2013). In contrast, the innate immune response induced by poly (I:C) in macrophages was inhibited by high concentrations of LL-37 $(5 \mu \mathrm{M})$ resulting in a decreased TNF- $\alpha$ and nitrite production as well as IL-1 $\beta$ and IL-6 mRNA expression (Hasan et al., 2011). This apparently paradoxical effect could be due to the capacity of LL-37 to inhibit phosphorylation of Ikb, MAPKs p38, and JNK induced by poly (I:C) in macrophages (Hasan et al., 2011). Thus, the LL-37-poly (I:C) complex could either prevent TLR3 activation or potentiate TLR3-dependant signaling (Singh et al., 2013).

Modulation of the innate immune response to TLR agonists was also demonstrated with hBD-3. Semple et al. (2015) observed an increased production of IFN- $\beta$, TNF- $\alpha$, CXCL- 8 , and IL- 6 in monocytes and PBMCs stimulated with poly (I:C) in presence of hBD-3. Higher levels of IFN- $\beta$ and TNF- $\alpha$ were also observed in transgenic mice expressing hBD-3 and stimulated with poly (I:C) as compared to control mice (Semple et al., 2015). In contrast to LL-37, hBD-3 doesn't form a complex with poly (I:C) to modulate 
its effects since the two molecules do not co-localize. However, hBD-3 altered poly (I:C) localization within the cell cytoplasm since, in the presence of $\mathrm{HBD}-3$, less poly (I:C) localized to the early endosome. The authors demonstrated that hBD-3 suppressed the poly (I:C)-induced TLR3 response mediated by TIR-domain-containing adapter-inducing interferon- $\beta$ (TRIF), while exacerbating the cytoplasmic response through MDA5 and MAVS (Vazquez and Horner, 2015).

In other hand, TLR9-mediated DNA sensing was strongly enhanced in presence of RNase 7 leading to secretion of antiviral level of IFN- $\alpha$ by human plasmacytoid DCs (Kopfnagel et al., 2018). Among the known immunomodulatory activities of RNase 7 (reviewed in Rademacher et al., 2019), it was shown that RNase 7 can contribute to antiviral immune response of human keratinocytes through promotion of selfDNA sensing (Kopfnagel et al., 2020). Indeed, pretreatment with both RNase 7 and DNA reduced HSV-1 replication in keratinocyte, a phenomenon mediated by induction of IFN- $\beta$ production (Kopfnagel et al., 2020).

AMPs are also able to modulate inflammatory response induced by viral infection. The addition of LL-37 to HRVinfected human bronchial epithelial cells enhanced IL-6 and CCL-2 production (Lai et al., 2011). It also increased the expression of type I IFN during VEEV infection (Lai et al., 2011; Ahmed et al., 2019b). However, paradoxical pro- and anti-inflammatory properties of LL-37 were also observed in the context of viral infection (Tripathi et al., 2014). In one hand, CXCL- 8 production induced by PMN infection with IAV was reduced in cell supernatant in presence of LL-37, while on the other, LL-37 enhanced PMN extracellular traps (NETs) formation and stimulated respiratory oxidative bursts in IAV-infected PMN (Tripathi et al., 2014). It is interesting to note that the anti-IAV mechanism of LL-37 through PMN activation was different from that reported for hNPs and hBD2 , which promoted virus aggregation and then phagocyte uptake by PMNs (Tecle et al., 2007). hBD-2 had also the ability to stimulate antiviral immunity both in vitro and in vivo (Kim et al., 2018). When conjugated with the receptor-binding domain of Middle East respiratory syndrome-coronavirus spike protein (SRBD), it significantly increased the expression levels of IFNs, IFN-stimulated genes and chemokines capable of recruiting leukocytes including macrophages, T cells, and DCs at the site of infection. In vivo, immunization of mice with hBD-2-conjugated S-RBD enhanced the immunogenicity of the S-RBD and elicited a higher S-RBD-specific neutralizing antibody response than S-RBD alone. Finally, hBD-4 may also enhance antiviral host protection. Administration of recombinant murine hBD-4 into animals immediately prior to IAV infection resulted in a significant increase of IFN- $\gamma$ concentration in bronchoalveolar lavage (LeMessurier et al., 2016).

\section{Chemotaxis and Immune Cell Activation}

In addition to cytokine and chemokine production modulation, keratinocyte AMPs can also modify the innate immune cell profile at the site of infection and inflammatory response. They can modulate the cellular composition of the inflammatory infiltrate but also the state of maturation and activation of the infiltrating cells.

\section{Chemotactic Properties of Keratinocyte AMPs}

AMPs can attract immune cells at the site of infection promoting an inflammatory context favorable to pathogen eradication. LL37, hBD-2, -3 , and -4 chemotactic activity has been observed on PMNs, T cells and monocytes (Figure 2; De et al., 2000; García et al., 2001; Röhrl et al., 2010). For hBDs, the mechanism was mediated through binding to the chemokine receptor CCR2 attracting CCR2-expressing inflammatory cells such as monocytes/macrophages, DCs, and PMNs to the sites of infection while LL-37 chemotactic activity was mediated by the G proteincoupled formyl peptide receptor-like 1 (FRPL-1) (De et al., 2000; Jia et al., 2008; Lin et al., 2008; Röhrl et al., 2010). In vivo, injection of hBD-2 in mice peritoneal cavity induced macrophage migration, a mechanism shown to be independent of the CCR6 receptor (Soruri et al., 2007). Other studies demonstrated an AMP-related chemotaxis on mast cells (Niyonsaba et al., 2002; Soruri et al., 2007). While hBD-2,-and LL-37 were shown to act as a specific mast cell chemotaxin through activation of G-proteinPLC-sensitive signaling pathway (Figure 2; Chen et al., 2007; Soruri et al., 2007), hBD3 and -4 were involved in mastcell chemotaxis through MAPK pathway activation (ERK, JNK, and p38 phosphorylation) (Soruri et al., 2007). Finally, hBD-2induced chemoattraction was also observed with immature DCs and memory $\mathrm{T}$ cells through CCR6 binding, while hBD-3, after CCR7 binding, promoted migration and lymph node localization of treated LC-DCs (Figure 2; Yang et al., 1999). Otherwise, S100 peptides may also display chemotactic activity. S100A7 was shown as a potent and selective chemotactic protein for CD $4+\mathrm{T}$ lymphocytes and PMNs but had no effect on monocytes (Jinquan et al., 1996). Chemotactic effect of the S100A8/A9 heterodimer was observed with macrophages and PMNs (Figure 2; Ryckman et al., 2003; Hiratsuka et al., 2008; Chen et al., 2015). Taken together, these data suggest that AMPs can favor the migration of immune cells crucial for mounting successful immune responses against viruses.

\section{Immune Cell Activation by Keratinocyte AMPs}

In addition to chemotaxis, keratinocyte AMPs can cause maturation and activation of innate immune cells. LL-37 enhanced CD86, CD83, and CCR7 expression on the surface of murine LCs indicating cell maturation (Figure 2; Ogawa et al., 2013). Moreover, incubation with hBD-3 resulted in monocyte and myeloid DCs maturation revealed by CD80, CD86, and CD40 upregulation (Figure 2). This was not observed with plasmacytoid DCs or B lymphocytes. MyD88 was involved in this maturation suggesting a TLR4-mediated process (Funderburg et al., 2007). Another study confirmed induction of phenotypic LC-DCs maturation by hBD-3 (Ferris et al., 2013). In the presence of the peptide, an increase in HLA-DR, CD83, CD86, and CCR7 expression on human immature LCs and DCs was assessed (Figure 2). These data also demonstrated that hBD-3 exposure allowed potent antigen presentation capacity in LCDCs and high levels of IFN- $\gamma$ production by primed T-cells suggesting that the peptide skewed cell activation toward a 


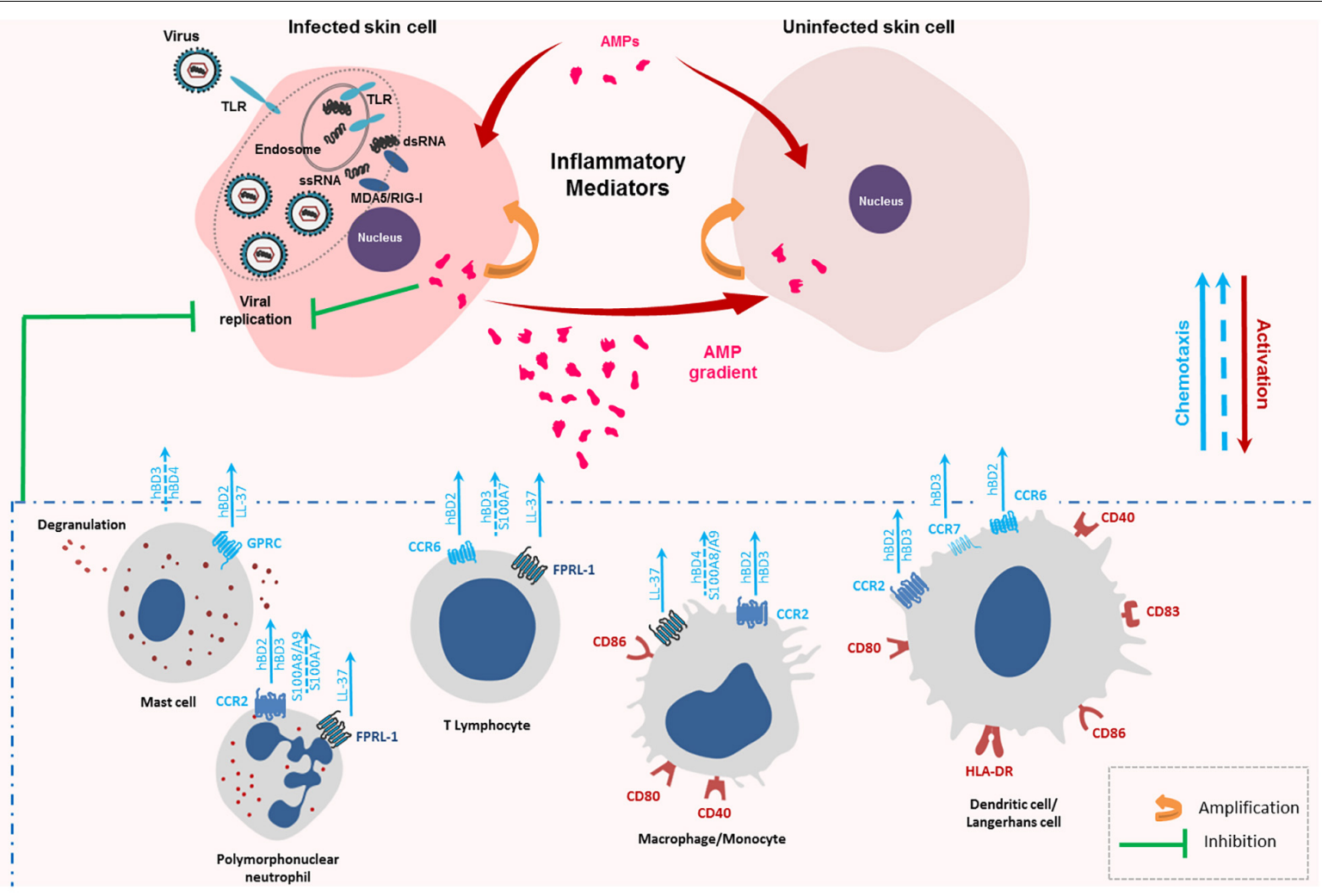

FIGURE 2 | Chemotactic and immune cell activation properties of keratinocyte antimicrobial peptides (AMPs). Keratinocytes infected with RNA viruses, such as arboviruses, sense viral single-stranded and double-stranded RNA generating an innate immune response made of cytokines, chemokines and AMPs. AMPs can then trigger the inflammatory response of the infected cells as well as non-infected cells. They also attract a wide range of immune cells at the site of the infection through several receptors as CC Chemokine Receptor (CCR)-2, CCR-6, CCR-7, and Formyl Peptide Receptor-Like (FPRL)-1 contributing to enhance the innate immune response and initiate the adaptative one. These receptor-dependent chemoattractant effects are represented with full blue arrows. Chemotactic effects described without identification of the AMP receptor are represented by a discontinuous blue arrow.

Th1-type immune response (Ferris et al., 2013). In addition to the binding to CCR6 and CCR2, hBD-3 was shown to interact with TLR1 and TLR2 on antigen-presenting cells, such as myeloid dendritic cells, leading to their activation (Funderburg et al., 2007). This peptide also induced the monocytes costimulatory molecules, CD80 and CD86, necessary for $\mathrm{T}$ cell activation (Figure 2; Petrov et al., 2013). Finally, Chen et al. (2007) demonstrated the abilities of hBD-3 and -4 to cause mast cell degranulation, prostaglandine $\mathrm{D} 2$ production and chemotaxis (Figure 2). Thus, AMPs, through their immune cell activation ability, can contribute to stimulate innate immunity and activate lymphocytes, key components of adaptive immunity against viruses.

\section{OTHER CELL MODIFICATION CAUSED BY KERATINOCYTE AMPS IMPACTING VIRAL INFECTION}

\section{Induction of APOBEC Expression}

Cell signaling pathways mediated by the chemokine receptor CCR6 also play a role in defensin-mediated HIV replication inhibition. hBD-2 treatment was shown to up-regulate expression of host restriction factor apolipoprotein $\mathrm{B}$ mRNA-editing enzyme-catalytic polypeptide-like 3G (APOBEC3G) in PBMCs or $\mathrm{CD} 4+\mathrm{T}$ cells. APOBEC3G is an HIV-1 restriction factor that inhibits the accumulation of early reverse transcription products during virus replication cycle (Wilson et al., 2013). This induction was mediated through the activation of CCR6 by hBD-2 (Lafferty et al., 2010).

\section{Modulation of Chemokine Receptor Expression at the Surface of the Target Cell}

Chemokine receptors CXCR4 and CCR5 are HIV-1 coreceptors in addition to $\mathrm{CD} 4$. The HIV-1 strains use either of these two co-receptors to infect CD4 + cells. hBD-2 and -3 reduced cell surface expression of CXCR4, but not CCR5, in PBMCs and a human $\mathrm{T}$ cell line (QuiñonesMateu et al., 2003; Feng et al., 2006). Those peptides, by modulating host surface receptors expression, acted as antiviral compound restricting cell binding and entry of HIV1 strain with CXCR4 tropism (Quiñones-Mateu et al., 2003; Feng et al., 2006). 
Conversely, LL-37 enhanced HIV-1 infection of monocytederived Langerhans cells (mLCs) (Ogawa et al., 2013). LL-37 treatment increased CCR5 and CD4 expression on mLCs surface, which could explain the potentiating effect of LL-37 on HIV1 infection. Effects of the peptide were also studied in DCs. Inhibition of HIV-1 infection was observed in LL-37 treated DCs, a phenomenon which may be due to down regulation of DC-SIGN and/or CCR5 expression (Ogawa et al., 2013). Finally, LL-37 facilitated HIV-1 transmission from mLCs to $\mathrm{CD} 4+\mathrm{T}$ cells whereas opposite effect was observed using DCs (Ogawa et al., 2013).

\section{CONCLUSION}

The keratinocyte is the target cell of many viruses of major importance in human health. As an immune cell that can detect viral PAMPs, it has the ability to secrete a wide range of molecules in response to the infection including many antimicrobial peptides. These peptides may then act directly on the viral particle or its replication cycle as well as modulate the innate immune response of the host. The first objective of this immunomodulation is likely to create an antiviral state by potentiating the production of cytokines and chemokines, and attracting immune cells to the site of infection. However, its precise role in the pathophysiology of viral infection remains to

\section{REFERENCES}

Aguirre, S., Maestre, A. M., Pagni, S., Patel, J. R., Savage, T., Gutman, D., et al. (2012). DENV inhibits type I IFN production in infected cells by cleaving human STING. PLoS Pathog. 8:e1002934. doi: 10.1371/journal.ppat.1002934

Ahmed, A., Siman-Tov, G., Hall, G., Bhalla, N., and Narayanan, A. (2019a). Human antimicrobial peptides as therapeutics for viral infections. Viruses 11:704. doi: 10.3390/v11080704

Ahmed, A., Siman-Tov, G., Keck, F., Kortchak, S., Bakovic, A., Risner, K., et al. (2019b). Human cathelicidin peptide LL-37 as a therapeutic antiviral targeting Venezuelan equine encephalitis virus infections. Antiviral Res. 164, 61-69. doi: 10.1016/j.antiviral.2019.02.002

Aksoy, O., Parlak, E., Parlak, M., and Aksoy, H. (2016). Serum $\beta$-Defensin-2 levels and their relationship with the clinical course and prognosis in patients with crimean-congo hemorrhagic fever. Med. Princ. Pract. 25, 163-168. doi: 10.1159/000442177

Alagarasu, K., Patil, P. S., Shil, P., Seervi, M., Kakade, M. B., Tillu, H., et al. (2017). In-vitro effect of human cathelicidin antimicrobial peptide LL-37 on dengue virus type 2. Peptides 92, 23-30. doi: 10.1016/j.peptides.2017.04.002

Ali, R. S., Falconer, A., Ikram, M., Bissett, C. E., Cerio, R., and Quinn, A. G. (2001). Expression of the peptide antibiotics human beta defensin-1 and human beta defensin-2 in normal human skin. J. Invest. Dermatol. 117, 106-111. doi: 10.1046/j.0022-202x.2001.01401.x

Almine, J. F., O’Hare, C. A., Dunphy, G., Haga, I. R., Naik, R. J., Atrih, A., et al. (2017). IFI16 and cGAS cooperate in the activation of STING during DNA sensing in human keratinocytes. Nat. Commun. 8:14392. doi: 10.1038/ ncomms 14392

Alvendal, C., Kamolvit, W., Wagner, S., Brauner, A., and Bohm-Starke, N. (2019). Expression of psoriasin in human papillomavirus-induced cervical high-grade squamous intraepithelial lesions. J. Low. Genit. Tract Dis. 23, 33-38. doi: 10.1097/LGT.0000000000000438

Bai, X., Tian, T., Wang, P., Yang, X., Wang, Z., and Dong, M. (2015). Potential roles of placental human beta-defensin-3 and apolipoprotein B mRNA-editing be defined. Furthermore, this dual mode of direct and indirect antiviral action suggests that AMPs may have a promising therapeutic role with direct virucidal activity and limited risk of engendering viral resistance. The deployment of such potentially impactful, innovative and reliable compounds awaits success in future research on how to effectively administer them and possibly stimulate them in situ.

\section{AUTHOR CONTRIBUTIONS}

$\mathrm{CC}$ and MG wrote the draft. $\mathrm{CB}, \mathrm{CJ}$, and NL contributed to the revision of the manuscript. MW designed the figures. All authors approved the final version of the manuscript.

\section{FUNDING}

This work was supported by grants from the Agence Nationale de la Recherche (ANR-17-CE35-0001-01).

\section{ACKNOWLEDGMENTS}

We sincerely thank Steven Tracy (Department of Pathology and Microbiology, Nebraska Medical Center) for having carefully reviewed this article.

enzyme catalytic polypeptide $3 \mathrm{G}$ in prevention of intrauterine transmission of hepatitis B virus. J. Med. Virol. 87, 375-379. doi: 10.1002/jmv.24072

Barlow, P. G., Findlay, E. G., Currie, S. M., and Davidson, D. J. (2014). Antiviral potential of cathelicidins. Future Microbiol. 9, 55-73.

Barlow, P. G., Svoboda, P., Mackellar, A., Nash, A. A., York, I. A., Pohl, J., et al. (2011). Antiviral activity and increased host defense against influenza infection elicited by the human cathelicidin LL-37. PLoS One 6:e25333. doi: 10.1371/ journal.pone.0025333

Becknell, B., and Spencer, J. D. (2016). A review of ribonuclease 7's structure, regulation, and contributions to host defense. Int. J. Mol. Sci. 17:423. doi: 10.3390/ijms 17030423

Bergman, P., Walter-Jallow, L., Broliden, K., Agerberth, B., and Söderlund, J. (2007). The antimicrobial peptide LL-37 inhibits HIV-1 replication. Curr. HIV Res. 5, 410-415. doi: 10.2174/157016207781023947

Boda, B., Benaoudia, S., Huang, S., Bonfante, R., Wiszniewski, L., Tseligka, E. D., et al. (2018). Antiviral drug screening by assessing epithelial functions and innate immune responses in human 3D airway epithelium model. Antiviral Res. 156, 72-79. doi: 10.1016/j.antiviral.2018.06.007

Boniface, K., Bernard, F. X., Garcia, M., Gurney, A. L., Lecron, J. C., and Morel, F. (2005). IL-22 inhibits epidermal differentiation and induces proinflammatory gene expression and migration of human keratinocytes. J. Immunol. 174, 3695-3702. doi: 10.4049/jimmunol.174.6. 3695

Boniotto, M., Jordan, W. J., Eskdale, J., Tossi, A., Antcheva, N., Crovella, S., et al. (2006). Human beta-defensin 2 induces a vigorous cytokine response in peripheral blood mononuclear cells. Antimicrob. Agents Chemother. 50, 1433-1441. doi: 10.1128/AAC.50.4.1433-1441.2006

Braff, M. H., Bardan, A., Nizet, V., and Gallo, R. L. (2005). Cutaneous defense mechanisms by antimicrobial peptides. J. Invest. Dermatol. 125, 9-13. doi: 10.1111/j.0022-202X.2004.23587.x

Brice, D. C., and Diamond, G. (2019). Antiviral activities of human host defense peptides. Curr. Med. Chem. 27, 1420-1443. doi: 10.2174/ 0929867326666190805151654 
Brice, D. C., Toth, Z., and Diamond, G. (2018). LL-37 disrupts the Kaposi's sarcoma-associated herpesvirus envelope and inhibits infection in oral epithelial cells. Antiviral Res. 158, 25-33. doi: 10.1016/j.antiviral.2018. 07.025

Büchau, A. S., Hassan, M., Kukova, G., Lewerenz, V., Kellermann, S., Würthner, J. U., et al. (2007). S100A15, an antimicrobial protein of the skin: regulation by E. coli through Toll-like receptor 4. J. Invest. Dermatol. 127, 2596-2604. doi: $10.1038 /$ sj.jid. 5700946

Buck, C. B., Day, P. M., Thompson, C. D., Lubkowski, J., Lu, W., Lowy, D. R., et al. (2006). Human alpha-defensins block papillomavirus infection. Proc. Natl. Acad. Sci. U.S.A. 103, 1516-1521.

Celis, J. E., Crüger, D., Kiil, J., Lauridsen, J. B., Ratz, G., Basse, B., et al. (1990). Identification of a group of proteins that are strongly up-regulated in total epidermal keratinocytes from psoriatic skin. FEBS Lett. 262, 159-164. doi: 10.1016/0014-5793(90)80179-m

Chen, B., Miller, A. L., Rebelatto, M., Brewah, Y., Rowe, D. C., Clarke, L., et al. (2015). S100A9 induced inflammatory responses are mediated by distinct damage associated molecular patterns (DAMP) receptors in vitro and in vivo. PLoS One 10:e0115828. doi: 10.1371/journal.pone.011 5828

Chen, W., Liu, Z., Zhang, Q., Yan, Q., and Jing, S. (2018). Induction and antiviral activity of human $\beta$-defensin 3 in intestinal cells with picornavirus infection. Acta Virol. 62, 287-293. doi: 10.4149/av_2018_222

Chen, X., Niyonsaba, F., Ushio, H., Hara, M., Yokoi, H., Matsumoto, K., et al. (2007). Antimicrobial peptides human beta-defensin (hBD)-3 and hBD-4 activate mast cells and increase skin vascular permeability. Eur. J. Immunol. 37, 434-444. doi: 10.1002/eji.200636379

Chong, K. T., Xiang, L., Wang, X., Jun, E. L., Xi, L. F., and Schweinfurth, J. M. (2006). High level expression of human epithelial beta-defensins (hBD-1, 2 and 3) in papillomavirus induced lesions. Virol J. 3:75. doi: 10.1186/1743-42 2X-3-75

Crack, L. R., Jones, L., Malavige, G. N., Patel, V., and Ogg, G. S. (2012). Human antimicrobial peptides LL-37 and human $\beta$-defensin-2 reduce viral replication in keratinocytes infected with varicella zoster virus. Clin. Exp. Dermatol. 37, 534-543. doi: 10.1111/j.1365-2230.2012.04305.x

Currie, S. M., Findlay, E. G., McHugh, B. J., Mackellar, A., Man, T., Macmillan, D., et al. (2013). The human cathelicidin LL-37 has antiviral activity against respiratory syncytial virus. PLoS One 8:e73659. doi: 10.1371/journal.pone. 0073659

Dalpke, A., and Helm, M. (2012). RNA mediated Toll-like receptor stimulation in health and disease. RNA Biol. 9, 828-842. doi: 10.4161/rna. 20206

De, Y., Chen, Q., Schmidt, A. P., Anderson, G. M., Wang, J. M., Wooters, J., et al. (2000). LL-37, the neutrophil granule- and epithelial cell-derived cathelicidin, utilizes formyl peptide receptor-like 1 (FPRL1) as a receptor to chemoattract human peripheral blood neutrophils, monocytes, and T cells. J. Exp. Med. 192, 1069-1074. doi: 10.1084/jem.192.7.1069

Dean, R. E., O'Brien, L. M., Thwaite, J. E., Fox, M. A., Atkins, H., and Ulaeto, D. O. (2010). A carpet-based mechanism for direct antimicrobial peptide activity against vaccinia virus membranes. Peptides 31, 1966-1972. doi: 10.1016/j. peptides.2010.07.028

Di Nardo, A., Vitiello, A., and Gallo, R. L. (2003). Cutting edge: mast cell antimicrobial activity is mediated by expression of cathelicidin antimicrobial peptide. J. Immunol. 170, 2274-2278. doi: 10.4049/jimmunol.170.5. 2274

Doss, M., White, M. R., Tecle, T., Gantz, D., Crouch, E. C., Jung, G., et al. (2009). Interactions of alpha-, beta-, and theta-defensins with influenza $\mathrm{A}$ virus and surfactant protein D. J. Immunol. 182, 7878-7887. doi: 10.4049/jimmunol. 0804049

Duangkhae, P., Erdos, G., Ryman, K. D., Watkins, S. C., Falo, L. D., Marques, E. T. A., et al. (2018). Interplay between keratinocytes and myeloid cells drives dengue virus spread in human skin. J. Invest. Dermatol. 138, 618-626. doi: 10.1016/j.jid.2017.10.018

Dugan, A. S., Maginnis, M. S., Jordan, J. A., Gasparovic, M. L., Manley, K., Page, R., et al. (2008). Human alpha-defensins inhibit BK virus infection by aggregating virions and blocking binding to host cells. J. Biol. Chem. 283, 31125-31132. doi: 10.1074/jbc.M805902200
Ehrchen, J. M., Sunderkötter, C., Foell, D., Vogl, T., and Roth, J. (2009). The endogenous Toll-like receptor 4 agonist S100A8/S100A9 (calprotectin) as innate amplifier of infection, autoimmunity, and cancer. J. Leukoc. Biol. 86, 557-566. doi: 10.1189/jlb.1008647

Erhart, W., Alkasi, Ö, Brunke, G., Wegener, F., Maass, N., Arnold, N., et al. (2011). Induction of human $\beta$-defensins and psoriasin in vulvovaginal human papillomavirus-associated lesions. J. Infect. Dis. 204, 391-399. doi: 10.1093/ infdis/jir079

Fathy, H., Amin, M. M., and El-Gilany, A. H. (2012). Upregulation of human $\beta$ defensin-3 and cathelicidin LL-37 in Kaposi's sarcoma. F1000Res. 1:38. doi: 10.12688/f1000research.1-38.v2

Feng, Z., Dubyak, G. R., Lederman, M. M., and Weinberg, A. (2006). Cutting edge: human beta defensin 3-a novel antagonist of the HIV-1 coreceptor CXCR4. J. Immunol. 177, 782-786. doi: 10.4049/jimmunol.177. 2.782

Ferris, L. K., Mburu, Y. K., Mathers, A. R., Fluharty, E. R., Larregina, A. T., Ferris, R. L., et al. (2013). Human beta-defensin 3 induces maturation of human langerhans cell-like dendritic cells: an antimicrobial peptide that functions as an endogenous adjuvant. J. Invest. Dermatol. 133, 460-468. doi: 10.1038/jid.2012. 319

Findlay, F., Pohl, J., Svoboda, P., Shakamuri, P., McLean, K., Inglis, N. F., et al. (2017). Carbon nanoparticles inhibit the antimicrobial activities of the human cathelicidin LL-37 through structural alteration. J. Immunol. 199, 2483-2490. doi: 10.4049/jimmunol.1700706

Firat, Y. H., Simanski, M., Rademacher, F., Schröder, L., Brasch, J., and Harder, J. (2014). Infection of keratinocytes with Trichophytum rubrum induces epidermal growth factor-dependent RNase 7 and human betadefensin-3 expression. PLoS One 9:e93941. doi: 10.1371/journal.pone.009 3941

Frohm, M., Agerberth, B., Ahangari, G., Stâhle-Bäckdahl, M., Lidén, S., Wigzell, H., et al. (1997). The expression of the gene coding for the antibacterial peptide LL37 is induced in human keratinocytes during inflammatory disorders. J. Biol. Chem. 272, 15258-15263. doi: 10.1074/jbc.272.24.15258

Fulton, C., Anderson, G. M., Zasloff, M., Bull, R., and Quinn, A. G. (1997). Expression of natural peptide antibiotics in human skin. Lancet 350, 1750-1751. doi: 10.1016/S0140-6736(05)63574-X

Funderburg, N., Lederman, M. M., Feng, Z., Drage, M. G., Jadlowsky, J., Harding, C. V., et al. (2007). Human -defensin-3 activates professional antigenpresenting cells via Toll-like receptors 1 and 2. Proc. Natl. Acad. Sci. U.S.A. 104, 18631-18635. doi: 10.1073/pnas.0702130104

Gabrielsen, T. O., Dale, I., Brandtzaeg, P., Hoel, P. S., Fagerhol, M. K., Larsen, T. E., et al. (1986). Epidermal and dermal distribution of a myelomonocytic antigen (L1) shared by epithelial cells in various inflammatory skin diseases. J. Am. Acad. Dermatol. 15(2 Pt 1), 173-179. doi: 10.1016/s0190-9622(86)70152-7

Ganz, T. (2002). Epithelia: not just physical barriers. Proc. Natl. Acad. Sci. U.S.A. 99, 3357-3358. doi: 10.1073/pnas.072073199

García, J. R., Krause, A., Schulz, S., Rodríguez-Jiménez, F. J., Klüver, E., Adermann, K., et al. (2001). Human beta-defensin 4: a novel inducible peptide with a specific salt-sensitive spectrum of antimicrobial activity. FASEB J. 15, 18191821

Garcia, M., Wehbe, M., Lévêque, N., and Bodet, C. (2017). Skin innate immune response to flaviviral infection. Eur. Cytokine Netw. 28, 41-51. doi: 10.1684/ ecn.2017.0394

Gasque, P., and Jaffar-Bandjee, M. C. (2015). The immunology and inflammatory responses of human melanocytes in infectious diseases. J. Infect. 71, 413-421. doi: 10.1016/j.jinf.2015.06.006

Gläser, R., Harder, J., Lange, H., Bartels, J., Christophers, E., and Schröder, J. M. (2005). Antimicrobial psoriasin (S100A7) protects human skin from Escherichia coli infection. Nat. Immunol. 6, 57-64. doi: 10.1038/ni1142

Gordon, Y. J., Huang, L. C., Romanowski, E. G., Yates, K. A., Proske, R. J., and McDermott, A. M. (2005). Human cathelicidin (LL-37), a multifunctional peptide, is expressed by ocular surface epithelia and has potent antibacterial and antiviral activity. Curr. Eye Res. 30, 385-394. doi: 10.1080/02713680590934111

Gourru-Lesimple, G., Mathieu, C., Thevenet, T., Guillaume-Vasselin, V., Jégou, J. F., Boer, C. G., et al. (2017). Measles virus infection of human keratinocytes: possible link between measles and atopic dermatitis. J. Dermatol. Sci. 86, 97-105. doi: 10.1016/j.jdermsci.2017.01.015 
Grice, E. A., and Segre, J. A. (2011). The skin microbiome. Nat. Rev. Microbiol. 9, 244-253.

Guilloteau, K., Paris, I., Pedretti, N., Boniface, K., Juchaux, F., Huguier, V., et al. (2010). Skin inflammation induced by the synergistic action of IL17A, IL-22, oncostatin M, IL-1\{alpha\}, and TNF-\{alpha\} recapitulates some features of psoriasis. J. Immunol. 184, 5263-5270. doi: 10.4049/jimmunol.090 2464

Hansdottir, S., Monick, M. M., Hinde, S. L., Lovan, N., Look, D. C., and Hunninghake, G. W. (2008). Respiratory epithelial cells convert inactive vitamin D to its active form: potential effects on host defense. J. Immunol. 181, 7090-7099. doi: 10.4049/jimmunol.181.10.7090

Harcourt, J. L., McDonald, M., Svoboda, P., Pohl, J., Tatti, K., and Haynes, L. M. (2016). Human cathelicidin, LL-37, inhibits respiratory syncytial virus infection in polarized airway epithelial cells. BMC Res. Notes. 9:11. doi: 10.1186/s13104015-1836-y

Harder, J., and Schroder, J. M. (2002). RNase 7, a novel innate immune defense antimicrobial protein of healthy human skin. J. Biol. Chem. 277, 46779-46784. doi: 10.1074/jbc.M207587200

Hasan, M., Ruksznis, C., Wang, Y., and Leifer, C. A. (2011). Antimicrobial peptides inhibit polyinosinic-polycytidylic acid-induced immune responses. J. Immunol. 187, 5653-5659. doi: 10.4049/jimmunol.1102144

Hattinger, E., Zwicker, S., Ruzicka, T., Yuspa, S. H., and Wolf, R. (2013). Opposing functions of psoriasin (S100A7) and koebnerisin (S100A15) in epithelial carcinogenesis. Curr. Opin. Pharmacol. 13, 588-594. doi: 10.1016/j.coph.2013. 04.007

Hazrati, E., Galen, B., Lu, W., Wang, W., Ouyang, Y., Keller, M. J., et al. (2006). Human alpha- and beta-defensins block multiple steps in herpes simplex virus infection. J. Immunol. 177, 8658-8666. doi: 10.4049/jimmunol.177.12.8658

He, M., Zhang, H., Li, Y., Wang, G., Tang, B., Zhao, J., et al. (2018). Cathelicidinderived antimicrobial peptides inhibit zika virus through direct inactivation and interferon pathway. Front. Immunol. 9:722. doi: 10.3389/fimmu.2018.00722

Hiratsuka, S., Watanabe, A., Sakurai, Y., Akashi-Takamura, S., Ishibashi, S., Miyake, K., et al. (2008). The S100A8-serum amyloid A3-TLR4 paracrine cascade establishes a pre-metastatic phase. Nat. Cell Biol. 10, 1349-1355. doi: 10.1038/ncb1794

Holly, M. K., Diaz, K., and Smith, J. G. (2017). Defensins in viral infection and pathogenesis. Annu. Rev. Virol. 4, 369-391. doi: 10.1146/annurev-virology101416-041734

Howell, M. D., Gallo, R. L., Boguniewicz, M., Jones, J. F., Wong, C., Streib, J. E., et al. (2006). Cytokine milieu of atopic dermatitis skin subverts the innate immune response to vaccinia virus. Immunity 24, 341-348. doi: 10.1016/j.immuni.2006. 02.006

Howell, M. D., Jones, J. F., Kisich, K. O., Streib, J. E., Gallo, R. L., and Leung, D. Y. (2004). Selective killing of vaccinia virus by LL-37: implications for eczema vaccinatum. J. Immunol. 172, 1763-1767. doi: 10.4049/jimmunol.172.3.1763

Howell, M. D., Streib, J. E., and Leung, D. Y. (2007). Antiviral activity of human beta-defensin 3 against vaccinia virus. J. Allergy Clin. Immunol. 119, 1022-1025. doi: 10.1016/j.jaci.2007.01.044

Hsieh, I. N., and Hartshorn, K. L. (2016). The role of antimicrobial peptides in influenza virus infection and their potential as antiviral and immunomodulatory therapy. Pharmaceuticals (Basel) 9:53. doi: 10.3390/ ph9030053

Hubert, P., Herman, L., Maillard, C., Caberg, J. H., Nikkels, A., Pierard, G., et al. (2007). Defensins induce the recruitment of dendritic cells in cervical human papillomavirus-associated (pre)neoplastic lesions formed in vitro and transplanted in vivo. FASEB J. 21, 2765-2775. doi: 10.1096/fj.06-7646com

Inoue, H., Shirakawa, J., Togashi, Y., Tajima, K., Okuyama, T., Kyohara, M., et al. (2018). Signaling between pancreatic $\beta$ cells and macrophages via S100 calciumbinding protein A8 exacerbates $\beta$-cell apoptosis and islet inflammation. J. Biol. Chem. 293, 5934-5946. doi: 10.1074/jbc.M117.809228

Jia, T., Serbina, N. V., Brandl, K., Zhong, M. X., Leiner, I. M., Charo, I. F., et al. (2008). Additive roles for MCP-1 and MCP-3 in CCR2-mediated recruitment of inflammatory monocytes during Listeria monocytogenes infection. J. Immunol. 180, 6846-6853. doi: 10.4049/jimmunol.180.10.6846

Jin, G., Kawsar, H. I., Hirsch, S. A., Zeng, C., Jia, X., Feng, Z., et al. (2010). An antimicrobial peptide regulates tumor-associated macrophage trafficking via the chemokine receptor CCR2, a model for tumorigenesis. PLoS One 5:e10993. doi: 10.1371/journal.pone.0010993
Jinquan, T., Vorum, H., Larsen, C. G., Madsen, P., Rasmussen, H. H., Gesser, B., et al. (1996). Psoriasin: a novel chemotactic protein. J. Invest. Dermatol. 107, 5-10.

Johnston, L. J., Halliday, G. M., and King, N. J. (1996). Phenotypic changes in Langerhans' cells after infection with arboviruses: a role in the immune response to epidermally acquired viral infection? J. Virol. 70, 4761-4766.

Johnston, L. J., Halliday, G. M., and King, N. J. (2000). Langerhans cells migrate to local lymph nodes following cutaneous infection with an arbovirus. J. Invest. Dermatol. 114, 560-568. doi: 10.1046/j.1523-1747.2000. 00904.x

Kalali, B. N., Köllisch, G., Mages, J., Müller, T., Bauer, S., Wagner, H., et al. (2008). Double-stranded RNA induces an antiviral defense status in epidermal keratinocytes through TLR3-, PKR-, and MDA5/RIG-I-mediated differential signaling. J. Immunol. 181, 2694-2704. doi: 10.4049/jimmunol.181.4.2694

Kanda, N., Kamata, M., Tada, Y., Ishikawa, T., Sato, S., and Watanabe, S. (2011). Human $\beta$-defensin- 2 enhances IFN- $\gamma$ and IL-10 production and suppresses IL-17 production in T cells. J. Leukoc. Biol. 89, 935-944. doi: 10.1189/jlb. 0111004

Kim, J., Yang, Y. L., Jang, S. H., and Jang, Y. S. (2018). Human $\beta$-defensin 2 plays a regulatory role in innate antiviral immunity and is capable of potentiating the induction of antigen-specific immunity. Virol J. 15:124. doi: 10.1186/s12985018-1035-2

Klotman, M. E., and Chang, T. L. (2006). Defensins in innate antiviral immunity. Nat. Rev. Immunol. 6, 447-456.

Koczulla, A. R., and Bals, R. (2003). Antimicrobial peptides: current status and therapeutic potential. Drugs 63, 389-406. doi: 10.2165/00003495-20036304000005

Kopfnagel, V., Dreyer, S., Baumert, K., Stark, M., Harder, J., Hofmann, K., et al. (2020). RNase 7 promotes sensing of Self-DNA by human keratinocytes and activates an antiviral immune response. J. Invest. Dermatol. S0022202X(20)30039-7. doi: 10.1016/j.jid.2019.09.029

Kopfnagel, V., Wagenknecht, S., Harder, J., Hofmann, K., Kleine, M., Buch, A., et al. (2018). RNase 7 strongly promotes TLR9-mediated DNA sensing by human plasmacytoid dendritic cells. J. Invest. Dermatol. 138, 872-881. doi: 10.1016/j.jid.2017.09.052

Kota, S., Sabbah, A., Chang, T. H., Harnack, R., Xiang, Y., Meng, X., et al. (2008). Role of human beta-defensin-2 during tumor necrosis factor-alpha/NFkappaB-mediated innate antiviral response against human respiratory syncytial virus. J. Biol. Chem. 283, 22417-22429. doi: 10.1074/jbc.M710415200

Kozlyuk, N., Monteith, A. J., Garcia, V., Damo, S. M., Skaar, E. P., and Chazin, W. J. (2019). S100 proteins in the innate immune response to pathogens. Methods Mol. Biol. 1929, 275-290. doi: 10.1007/978-1-4939-9030-6_18

Kubo, A., Nagao, K., Yokouchi, M., Sasaki, H., and Amagai, M. (2009). External antigen uptake by langerhans cells with reorganization of epidermal tight junction barriers. J. Exp. Med. 206, 2937-2946. doi: 10.1084/jem.20091527

Kunz, M., Roth, J., Sorg, C., and Kolde, G. (1992). Epidermal expression of the calcium binding surface antigen 27E10 in inflammatory skin diseases. Arch. Dermatol. Res. 284, 386-390. doi: 10.1007/BF00372067

Lafferty, M. K., Sun, L., DeMasi, L., Lu, W., and Garzino-Demo, A. (2010). CCR6 ligands inhibit HIV by inducing APOBEC3G. Blood 115, 1564-1571. doi: 10.1182/blood-2009-06-226423

Lai, Y., Adhikarakunnathu, S., Bhardwaj, K., Ranjith-Kumar, C. T., Wen, Y., Jordan, J. L., et al. (2011). LL37 and cationic peptides enhance TLR3 signaling by viral double-stranded RNAs. PLoS One 6:e26632. doi: 10.1371/journal.pone. 0026632

Lai, Y., and Gallo, R. L. (2009). AMPed up immunity: how antimicrobial peptides have multiple roles in immune defense. Trends Immunol. 30, 131-141. doi: 10.1016/j.it.2008.12.003

Lau, Y. E., Rozek, A., Scott, M. G., Goosney, D. L., Davidson, D. J., and Hancock, R. E. (2005). Interaction and cellular localization of the human host defense peptide LL-37 with lung epithelial cells. Infect. Immun. 73, 583-591. doi: 10.1128/IAI.73.1.583-591.2005

Lee, A. Y., and Körner, H. (2017). CCR6/CCL20 chemokine axis in human immunodeficiency virus immunity and pathogenesis. J. Gen. Virol. 98, 338-344. doi: 10.1099/jgv.0.000691

Lee, C. J., Buznyk, O., Kuffova, L., Rajendran, V., Forrester, J. V., Phopase, J., et al. (2014). Cathelicidin LL-37 and HSV-1 corneal infection: peptide versus gene therapy. Transl. Vis. Sci. Technol. 3:4. doi: 10.1167/tvst.3.3.4 
Lehrer, R. I., and Ganz, T. (1999). Antimicrobial peptides in mammalian and insect host defence. Curr. Opin. Immunol. 11, 23-27. doi: 10.1016/s0952-7915(99) 80005-3

Lei, J., Sun, L., Huang, S., Zhu, C., Li, P., He, J., et al. (2019). The antimicrobial peptides and their potential clinical applications. Am. J. Transl. Res. 11, 39193931.

LeMessurier, K. S., Lin, Y., McCullers, J. A., and Samarasinghe, A. E. (2016). Antimicrobial peptides alter early immune response to influenza A virus infection in C57BL/6 mice. Antiviral Res. 133, 208-217. doi: 10.1016/j.antiviral. 2016.08.013

Lim, P. Y., Behr, M. J., Chadwick, C. M., Shi, P. Y., and Bernard, K. A. (2011), Keratinocytes are cell targets of West Nile virus in vivo. J. Virol. 85, 5197-5201. doi: 10.1128/JVI.02692-10

Lin, K. L., Suzuki, Y., Nakano, H., Ramsburg, E., and Gunn, M. D. (2008). CCR2+ monocyte-derived dendritic cells and exudate macrophages produce influenza-induced pulmonary immune pathology and mortality. J. Immunol. 180, 2562-2572. doi: 10.4049/jimmunol.180.4.2562

López-González, M., Meza-Sánchez, D., García-Cordero, J., Bustos-Arriaga, J., Vélez-Del Valle, C., Marsch-Moreno, M., et al. (2018). Human keratinocyte cultures $(\mathrm{HaCaT})$ can be infected by DENV, triggering innate immune responses that include IFN $\lambda$ and LL37. Immunobiology 223, 608-617. doi: 10.1016/j.imbio.2018.07.006

Matsumura, T., Sugiyama, N., Murayama, A., Yamada, N., Shiina, M., Asabe, S., et al. (2016). Antimicrobial peptide LL-37 attenuates infection of hepatitis C virus. Hepatol. Res. 46, 924-932. doi: 10.1111/hepr.12627

Mattar, E. H., Almehdar, H. A., AlJaddawi, A. A., Abu Zeid, I. E., and Redwan, E. M. (2016a). Elevated concentration of defensins in hepatitis $C$ virus-infected patients. J. Immunol. Res. 2016:8373819. doi: 10.1155/2016/8373819

Mattar, E. H., Almehdar, H. A., Uversky, V. N., and Redwan, E. M. (2016b). Virucidal activity of human $\alpha$ - and $\beta$-defensins against hepatitis C virus genotype 4. Mol. Biosyst. 12, 2785-2797. doi: 10.1039/c6mb00 $283 \mathrm{~h}$

Mookherjee, N., Hamill, P., Gardy, J., Blimkie, D., Falsafi, R., Chikatamarla, A., et al. (2009). Systems biology evaluation of immune responses induced by human host defence peptide LL-37 in mononuclear cells. Mol. Biosyst. 5, 483-496. doi: 10.1039/b813787k

Murakami, M., Ohtake, T., Dorschner, R. A., Schittek, B., Garbe, C., and Gallo, R. L. (2002). Cathelicidin anti-microbial peptide expression in sweat, an innate defense system for the skin. J. Invest. Dermatol. 119, 1090-1095. doi: 10.1046/j. 1523-1747.2002.19507.x

Nestle, F. O., Di Meglio, P., Qin, J. Z., and Nickoloff, B. J. (2009). Skin immune sentinels in health and disease. Nat. Rev. Immunol. 9, 679-691. doi: 10.1038/ nri2622

Niyonsaba, F., Hattori, F., Maeyama, K., Ogawa, H., and Okamoto, K. (2008). Induction of a microbicidal protein psoriasin (S100A7), and its stimulatory effects on normal human keratinocytes. J. Dermatol. Sci. 52, 216-219. doi: 10.1016/j.jdermsci.2008.07.003

Niyonsaba, F., Iwabuchi, K., Someya, A., Hirata, M., Matsuda, H., Ogawa, H., et al. (2002). A cathelicidin family of human antibacterial peptide LL-37 induces mast cell chemotaxis. Immunology 106, 20-26. doi: 10.1046/j.1365-2567.2002. 01398.x

Niyonsaba, F., Ushio, H., Nagaoka, I., Okumura, K., and Ogawa, H. (2005). The human beta-defensins $(-1,-2,-3,-4)$ and cathelicidin LL-37 induce IL18 secretion through p38 and ERK MAPK activation in primary human keratinocytes. J. Immunol. 175, 1776-1784. doi: 10.4049/jimmunol.175.3.1776

Niyonsaba, F., Ushio, H., Nakano, N., Ng, W., Sayama, K., Hashimoto, K., et al. (2007). Antimicrobial peptides human beta-defensins stimulate epidermal keratinocyte migration, proliferation and production of proinflammatory cytokines and chemokines. J. Invest. Dermatol. 127, 594-604. doi: 10.1038/sj. jid.5700599

Ogawa, Y., Kawamura, T., Matsuzawa, T., Aoki, R., Gee, P., Yamashita, A., et al. (2013). Antimicrobial peptide LL-37 produced by HSV-2-infected keratinocytes enhances HIV infection of Langerhans cells. Cell Host Microbe 13, 77-86. doi: 10.1016/j.chom.2012.12.002

Oppenheim, J. J., Biragyn, A., Kwak, L. W., and Yang, D. (2003). Roles of antimicrobial peptides such as defensins in innate and adaptive immunity. Ann. Rheum. Dis. 62(Suppl. 2), ii17-ii21. doi: 10.1136/ard.62.suppl_2.ii17
Ostergaard, M., Wolf, H., Orntoft, T. F., and Celis, J. E. (1999). Psoriasin (S100A7): a putative urinary marker for the follow-up of patients with bladder squamous cell carcinomas. Electrophoresis 20, 349-354. doi: 10.1002/(SICI) 1522-2683(19990201)20:2\&1t;349::AID-ELPS349\&gt;3.0.CO;2-B

Pace, B. T., Lackner, A. A., Porter, E., and Pahar, B. (2017). The role of defensins in HIV pathogenesis. Mediators Inflamm. 2017:5186904.

Petrov, V., Funderburg, N., Weinberg, A., and Sieg, S. (2013). Human $\beta$ defensin-3 induces chemokines from monocytes and macrophages: diminished activity in cells from HIV-infected persons. Immunology 140, 413-420. doi: 10.1111/imm. 12148

Phyu, W. K., Ong, K. C., Kong, C. K., Alizan, A. K., Ramanujam, T. M., and Wong, K. T. (2017). Squamous epitheliotropism of Enterovirus A71 in human epidermis and oral mucosa. Sci. Rep. 7:45069. doi: 10.1038/srep45069

Pingen, M., Bryden, S. R., Pondeville, E., Schnettler, E., Kohl, A., Merits, A., et al. (2016). Host inflammatory response to mosquito bites enhances the severity of arbovirus infection. Immunity 44, 1455-1469. doi: 10.1016/j.immuni.2016.06. 002

Proud, D., Sanders, S. P., and Wiehler, S. (2004). Human rhinovirus infection induces airway epithelial cell production of human beta-defensin 2 both in vitro and in vivo. J. Immunol. 172, 4637-4645. doi: 10.4049/jimmunol.172.7.4637

Puiprom, O., Morales Vargas, R. E., Potiwat, R., Chaichana, P., Ikuta, K., Ramasoota, P., et al. (2013). Characterization of chikungunya virus infection of a human keratinocyte cell line: role of mosquito salivary gland protein in suppressing the host immune response. Infect. Genet. Evol. 17, 210-215. doi: 10.1016/j.meegid.2013.04.005

Pulido, D., Torrent, M., Andreu, D., Nogués, M. V., and Boix, E. (2013). Two human host defense ribonucleases against mycobacteria, the eosinophil cationic protein (RNase 3) and RNase 7. Antimicrob. Agents Chemother. 57, 3797-3805. doi: 10.1128/AAC.00428-13

Quiñones-Mateu, M. E., Lederman, M. M., Feng, Z., Chakraborty, B., Weber, J., Rangel, H. R., et al. (2003). Human epithelial beta-defensins 2 and 3 inhibit HIV-1 replication. AIDS 17, F39-F48. doi: 10.1097/00002030-20031107000001

Rademacher, F., Dreyer, S., Kopfnagel, V., Gläser, R., Werfel, T., and Harder, J. (2019). The antimicrobial and immunomodulatory function of RNase 7 in skin. Front. Immunol. 10:2553. doi: 10.3389/fimmu.2019.02553

Rademacher, F., Simanski, M., and Harder, J. (2016). RNase 7 in cutaneous defense. Int. J. Mol. Sci. 17:560

Reghunathan, R., Jayapal, M., Hsu, L. Y., Chng, H. H., Tai, D., Leung, B. P., et al. (2005). Expression profile of immune response genes in patients with severe acute respiratory syndrome. BMC Immunol. 6:2. doi: 10.1186/1471-2172-6-2

Robert, C., and Kupper, T. S. (1999). Inflammatory skin diseases, T cells, and immune surveillance. N. Engl. J. Med. 341, 1817-1828. doi: 10.1056/ NEJM199912093412407

Röhrl, J., Yang, D., Oppenheim, J. J., and Hehlgans, T. (2010). Human beta-defensin 2 and 3 and their mouse orthologs induce chemotaxis through interaction with CCR2. J. Immunol. 184, 6688-6694. doi: 10.4049/jimmunol.0903984

Ryan, L. K., Dai, J., Yin, Z., Megjugorac, N., Uhlhorn, V., Yim, S., et al. (2011). Modulation of human beta-defensin-1 (hBD-1) in plasmacytoid dendritic cells (PDC), monocytes, and epithelial cells by influenza virus, Herpes simplex virus, and Sendai virus and its possible role in innate immunity. J. Leukoc. Biol. 90, 343-356. doi: 10.1189/jlb.0209079

Ryckman, C., Vandal, K., Rouleau, P., Talbot, M., and Tessier, P. A. (2003). Proinflammatory activities of S100: proteins S100A8, S100A9, and S100A8/A9 induce neutrophil chemotaxis and adhesion. J. Immunol. 170, 3233-3242. doi: 10.4049/jimmunol.170.6.3233

Sato, E., Hiromatsu, K., Murata, K., and Imafuku, S. (2018). Loss of ATP2A2 allows herpes simplex virus 1 infection of a human epidermis model by disrupting innate immunity and barrier function. J. Invest. Dermatol. 138, 2540-2549. doi: $10.1016 /$ j.jid.2018.05.019

Sayers, C. L., and Elliott, G. (2016). Herpes simplex virus 1 enters human keratinocytes by a Nectin-1-dependent, rapid plasma membrane fusion pathway that functions at low temperature. J. Virol. 90, 10379-10389. doi: 10.1128/JVI.01582-16

Schmid, M. A., and Harris, E. (2014). Monocyte recruitment to the dermis and differentiation to dendritic cells increases the targets for dengue virus replication. PLoS Pathog. 10:e1004541. doi: 10.1371/journal.ppat.1004541 
Schögler, A., Muster, R. J., Kieninger, E., Casaulta, C., Tapparel, C., Jung, A., et al. (2016). Vitamin D represses rhinovirus replication in cystic fibrosis cells by inducing LL-37. Eur. Respir. J. 47, 520-530. doi: 10.1183/13993003.006 65-2015

Scudiero, O., Galdiero, S., Cantisani, M., Di Noto, R., Vitiello, M., Galdiero, M. et al. (2010). Novel synthetic, salt-resistant analogs of human beta-defensins 1 and 3 endowed with enhanced antimicrobial activity. Antimicrob. Agents Chemother. 54, 2312-2322. doi: 10.1128/AAC.01550-09

Semple, F., and Dorin, J. R. (2012). $\beta$-Defensins: multifunctional modulators of infection, inflammation and more? J. Innate Immun. 4, 337-348. doi: 10.1159/ 000336619

Semple, F., MacPherson, H., Webb, S., Kilanowski, F., Lettice, L., McGlasson, S. L., et al. (2015). Human $\beta-D-3$ exacerbates MDA5 but suppresses TLR3 responses to the viral molecular pattern mimic polyinosinic:polycytidylic acid. PLoS Genet. 11:e1005673. doi: 10.1371/journal.pgen.1005673

Sharif, S., Nakatani, Y., Wise, L., Corbett, M., Real, N. C., Stuart, G. S., et al. (2016). A broad-spectrum chemokine-binding protein of bovine papular stomatitis virus inhibits neutrophil and monocyte infiltration in inflammatory and wound models of mouse skin. PLoS One 11:e0168007. doi: 10.1371/journal.pone. 0168007

Simanski, M., Rademacher, F., Schröder, L., Schumacher, H. M., Gläser, R., and Harder, J. (2013). IL-17A and IFN- $\gamma$ synergistically induce RNase 7 expression via STAT3 in primary keratinocytes. PLoS One 8:e59531. doi: 10.1371/journal. pone. 0059531

Singh, D., Qi, R., Jordan, J. L., San Mateo, L., and Kao, C. C. (2013). The human antimicrobial peptide LL-37, but not the mouse ortholog, mCRAMP, can stimulate signaling by poly(I:C) through a FPRL1-dependent pathway. J. Biol. Chem. 288, 8258-8268. doi: 10.1074/jbc.M112.440883

Smithrithee, R., Niyonsaba, F., Kiatsurayanon, C., Ushio, H., Ikeda, S., Okumura, K., et al. (2015). Human $\beta$-defensin- 3 increases the expression of interleukin37 through CCR6 in human keratinocytes. J. Dermatol. Sci. 77, 46-53. doi: 10.1016/j.jdermsci.2014.12.001

Sørensen, O. E., Follin, P., Johnsen, A. H., Calafat, J., Tjabringa, G. S., Hiemstra, P. S., et al. (2001). Human cathelicidin, hCAP-18, is processed to the antimicrobial peptide LL-37 by extracellular cleavage with proteinase 3. Blood 97, 3951-3959. doi: 10.1182/blood.v97.12.3951

Soruri, A., Grigat, J., Forssmann, U., Riggert, J., and Zwirner, J. (2007). betaDefensins chemoattract macrophages and mast cells but not lymphocytes and dendritic cells: CCR6 is not involved. Eur. J. Immunol. 37, 2474-2486. doi: 10.1002/eji.200737292

Sousa, F. H., Casanova, V., Findlay, F., Stevens, C., Svoboda, P., Pohl, J., et al. (2017). Cathelicidins display conserved direct antiviral activity towards rhinovirus. Peptides 95, 76-83. doi: 10.1016/j.peptides.2017.07.013

Sun, L., Finnegan, C. M., Kish-Catalone, T., Blumenthal, R., Garzino-Demo, P., La Terra Maggiore, G. M., et al. (2005). Human beta-defensins suppress human immunodeficiency virus infection: potential role in mucosal protection. J. Virol. 79, 14318-14329. doi: 10.1128/JVI.79.22.14318-14329.2005

Sunahori, K., Yamamura, M., Yamana, J., Takasugi, K., Kawashima, M., Yamamoto, H., et al. (2006). The S100A8/A9 heterodimer amplifies proinflammatory cytokine production by macrophages via activation of nuclear factor kappa B and p38 mitogen-activated protein kinase in rheumatoid arthritis. Arthritis Res. Ther. 8:R69. doi: 10.1186/ar1939

Surasombatpattana, P., Hamel, R., Patramool, S., Luplertlop, N., Thomas, F., Desprès, P., et al. (2011). Dengue virus replication in infected human keratinocytes leads to activation of antiviral innate immune responses. Infect. Genet. Evol. 11, 1664-1673. doi: 10.1016/j.meegid.2011.06.009

Szukiewicz, D., Alkhalayla, H., Pyzlak, M., Watroba, M., Szewczyk, G., and Wejman, J. (2016). Human beta-defensin 1, 2 and 3 production by amniotic epithelial cells with respect to human papillomavirus (HPV) infection, HPV oncogenic potential and the mode of delivery. Microb. Pathog. 97, 154-165. doi: $10.1016 /$ j.micpath.2016.06.010

Takeuchi, O., and Akira, S. (2009). Innate immunity to virus infection. Immunol. Rev. 227, 75-86.

Takiguchi, T., Morizane, S., Yamamoto, T., Kajita, A., Ikeda, K., and Iwatsuki, K. (2014). Cathelicidin antimicrobial peptide LL-37 augments interferon$\beta$ expression and antiviral activity induced by double-stranded RNA in keratinocytes. Br. J. Dermatol. 171, 492-498. doi: 10.1111/bjd.12942
Tecle, T., White, M. R., Gantz, D., Crouch, E. C., and Hartshorn, K. L. (2007). Human neutrophil defensins increase neutrophil uptake of influenza A virus and bacteria and modify virus-induced respiratory burst responses. J. Immunol. 178, 8046-8052. doi: 10.4049/jimmunol.178.12.8046

Thorey, I. S., Roth, J., Regenbogen, J., Halle, J. P., Bittner, M., Vogl, T., et al. (2001). The Ca2+-binding proteins S100A8 and S100A9 are encoded by novel injury-regulated genes. J. Biol. Chem. 276, 35818-35825. doi: 10.1074/jbc. M104871200

Tjabringa, G. S., Ninaber, D. K., Drijfhout, J. W., Rabe, K. F., and Hiemstra, P. S. (2006). Human cathelicidin LL-37 is a chemoattractant for eosinophils and neutrophils that acts via formyl-peptide receptors. Int. Arch. Allergy Immunol. 140, 103-112. doi: 10.1159/000092305

Tripathi, S., Tecle, T., Verma, A., Crouch, E., White, M., and Hartshorn, K. L. (2013). The human cathelicidin LL-37 inhibits influenza A viruses through a mechanism distinct from that of surfactant protein D or defensins. J. Gen. Virol. 94(Pt 1), 40-49. doi: 10.1099/vir.0.045013-0

Tripathi, S., Verma, A., Kim, E. J., White, M. R., and Hartshorn, K. L. (2014). LL-37 modulates. J. Leukoc. Biol. 96, 931-938.

Tugizov, S., Berline, J., Herrera, R., Penaranda, M. E., Nakagawa, M., and Palefsky, J. (2005). Inhibition of human papillomavirus type 16 E7 phosphorylation by the S100 MRP-8/14 protein complex. J. Virol. 79, 1099-1112. doi: 10.1128/JVI. 79.2.1099-1112.2005

Uchio, E., Inoue, H., and Kadonosono, K. (2013). Anti-adenoviral effects of human cationic antimicrobial protein-18/LL-37, an antimicrobial peptide, by quantitative polymerase chain reaction. Korean J. Ophthalmol. 27, 199-203. doi: 10.3341/kjo.2013.27.3.199

Ulaeto, D. O., Morris, C. J., Fox, M. A., Gumbleton, M., and Beck, K. (2016). Destabilization of $\alpha$-Helical structure in solution improves bactericidal activity of antimicrobial peptides: opposite effects on bacterial and viral targets. Antimicrob. Agents Chemother. 60, 1984-1991. doi: 10.1128/AAC.02146-15

Vazquez, C., and Horner, S. M. (2015). MAVS Coordination of antiviral innate immunity. J. Virol. 89, 6974-6977. doi: 10.1128/JVI.01918-14

Vilas Boas, L. C., de Lima, L. M., Migliolo, L., Mendes, G. D., de Jesus, M. G., Franco, O. L., et al. (2017). Linear antimicrobial peptides with activity against herpes simplex virus 1 and Aichi virus. Biopolymers 108:e22871. doi: 10.1002/ bip. 22871

Voss, A., Bode, G., Sopalla, C., Benedyk, M., Varga, G., Böhm, M., et al. (2011). Expression of S100A8/A9 in HaCaT keratinocytes alters the rate of cell proliferation and differentiation. FEBS Lett. 585, 440-446. doi: 10.1016/j. febslet.2010.12.037

Watson, P. H., Leygue, E. R., and Murphy, L. C. (1998). Psoriasin (S100A7). Int. J. Biochem. Cell Biol. 30, 567-571.

Welte, T., Reagan, K., Fang, H., Machain-Williams, C., Zheng, X., Mendell, N., et al. (2009). Toll-like receptor 7-induced immune response to cutaneous West Nile virus infection. J. Gen. Virol. 90(Pt 11), 2660-2668. doi: 10.1099/vir.0.011783-0

Wilson, C. L., Ouellette, A. J., Satchell, D. P., Ayabe, T., López-Boado, Y. S., Stratman, J. L., et al. (1999). Regulation of intestinal alpha-defensin activation by the metalloproteinase matrilysin in innate host defense. Science 286, 113117. doi: $10.1126 /$ science. 286.5437 .113

Wilson, S. S., Wiens, M. E., and Smith, J. G. (2013). Antiviral mechanisms of human defensins. J. Mol. Biol. 425, 4965-4980.

Wolf, R., Ruzicka, T., and Yuspa, S. H. (2011). Novel S100A7 (psoriasin)/S100A15 (koebnerisin) subfamily: highly homologous but distinct in regulation and function. Amino Acids 41, 789-796. doi: 10.1007/s00726-010-0666-4

Wong, J. H., Legowska, A., Rolka, K., Ng, T. B., Hui, M., Cho, C. H., et al. (2011). Effects of cathelicidin and its fragments on three key enzymes of HIV-1. Peptides 32, 1117-1122. doi: 10.1016/j.peptides.2011.04.017

Yang, D., Chertov, O., Bykovskaia, S. N., Chen, Q., Buffo, M. J., Shogan, J., et al. (1999). Beta-defensins: linking innate and adaptive immunity through dendritic and T cell CCR6. Science 286, 525-528. doi: 10.1126/science.286.5439.525

Yong, H. Y., and Luo, D. (2018). RIG-I-Like receptors as novel targets for pan-antivirals and vaccine adjuvants against emerging and re-emerging viral infections. Front. Immunol. 9:1379. doi: 10.3389/fimmu.2018.01379

Yoshio, H., Tollin, M., Gudmundsson, G. H., Lagercrantz, H., Jornvall, H., Marchini, G., et al. (2003). Antimicrobial polypeptides of human vernix caseosa and amniotic fluid: implications for newborn innate defense. Pediatr. Res. 53, 211-216. doi: 10.1203/01.PDR.0000047471.47777.B0 
Zasloff, M. (2002). Antimicrobial peptides of multicellular organisms. Nature 415, 389-395. doi: 10.1007/978-981-13-35 88-4_1

Zheng, Y., Niyonsaba, F., Ushio, H., Ikeda, S., Nagaoka, I., Okumura, K., et al. (2008). Microbicidal protein psoriasin is a multifunctional modulator of neutrophil activation. Immunology 124, 357-367. doi: 10.1111/j.1365-2567. 2007.02782.x

Zhu, L., Okano, S., Takahara, M., Chiba, T., Tu, Y., Oda, Y., et al. (2013). Expression of S100 protein family members in normal skin and sweat gland tumors. J. Dermatol. Sci. 70, 211-219. doi: 10.1016/j.jdermsci.2013. 03.002
Conflict of Interest: The authors declare that the research was conducted in the absence of any commercial or financial relationships that could be construed as a potential conflict of interest.

Copyright $\odot 2020$ Chessa, Bodet, Jousselin, Wehbe, Lévêque and Garcia. This is an open-access article distributed under the terms of the Creative Commons Attribution License (CC BY). The use, distribution or reproduction in other forums is permitted, provided the original author(s) and the copyright owner(s) are credited and that the original publication in this journal is cited, in accordance with accepted academic practice. No use, distribution or reproduction is permitted which does not comply with these terms. 